\title{
ROCHAS CLÁSTICAS DO PLANALTO DE POÇOS DE CALDAS
}

Alfredo José Simon Bjornberg
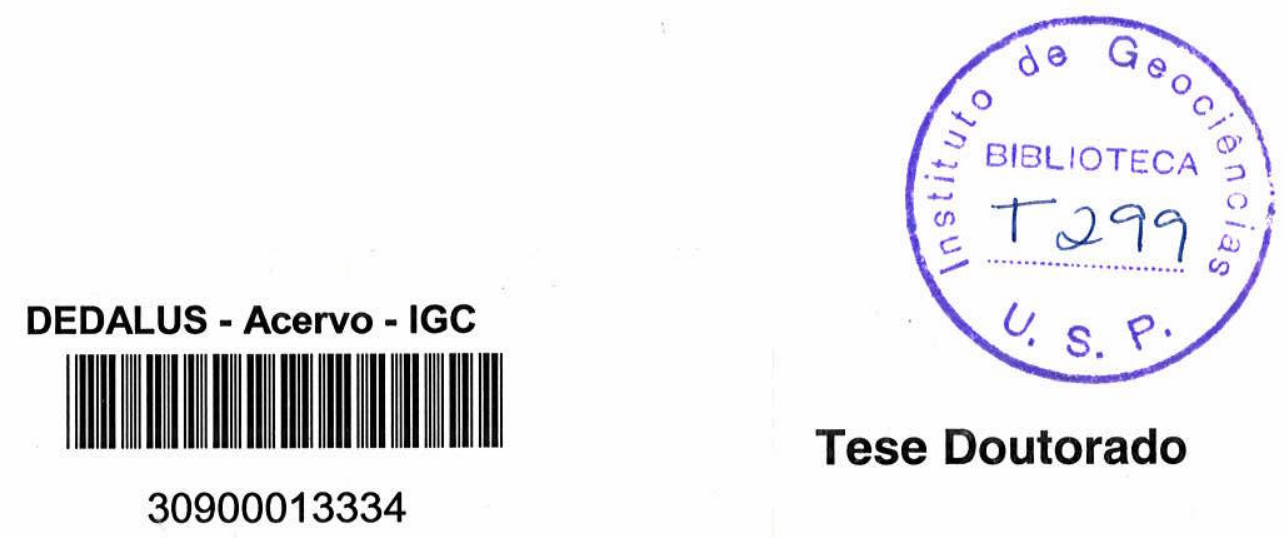

Tese Doutorado

\section{8}




\section{Ondidivencess}

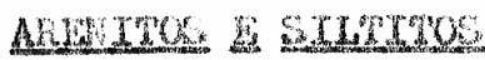

Colete de sedimentos

Anclise mecânLes

Lorras dos coraponentes

Brtho _ho

Anglise mineralogice …… 10

Mnerais pesados _- 11

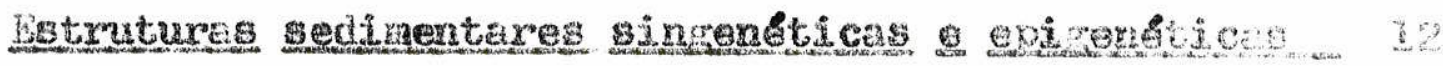

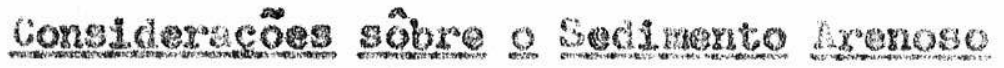

Mriser a Eabiente de sedimentecio

Idade dos arenitos

4 drons

Descresto

Considexacōes gerais sôbre as brechs

Zdade dos breches

AD HOCHAS CLESTCAS WO EJEGO

Oxplarn das brechas

Las grondes estruturas

Abatimento, erosão ou explosẽo?

Coversuson: 


ROCHAS CLASTICAS DO PLANALTO
POÇOS DE
DE CALDAS

INTRODUCLO: 0 escopo do present trabalho o estudo das rochas clásticas do planalto de Poços de Caldas, sul do Estado de Minas Gerais, enquadrado nas longitudes de $46^{\circ}$ e $47^{\circ} \mathrm{W}$ (Greenwich) e nas latitudes de $21^{\circ}$ - $22^{\circ} \mathrm{S}$. Em meados de 1954, O Dr. Jos6 Moacir V. Coutinho, O Sr. Reinholt Ellert eu iniciamos os trabalhos de campo no planalto do Poģos de Caldas. Estes trabalhos foram executados principalmente durante as férias escolares da Universidade de S.P.. Como o trabalho de cada um de nós seria assunto para tese, foi êle dividido m diversas partes a serem tratadas separadamente. A mim coub o estudo das rochas clasticas. Entretanto, o Ievantamento geolbgico geral foi feito em conjunto.

A dificuldade infial encontrada foi a da falta de cartas topográfjcas adequadas que servissem para o mapeamento das diversas formações, posteriorment sanada com a obtenção de mapes precisos atualizados. 0 mapa definitivo fol traçado na oscala de 1:50.000, que se encontra anexo.

joços de Caldas uma das maiores ocorrências de rochas alcalinas do globo. Situa-se nos limites de São Paulo Minas gerais, junto aos contrafortes da Serra da Mentiqueira, entre as cabeceiras do Rio Pardo Mogiguassu. I rodeada por uma cinta de rochas sedimentares clásticas, que testemunharam registraram os importantes acontecimentos geologicos, que af tomaram parte, incluindo o vulcanismo. Dêsse modo, as rochas sedimentares têm importante papel na datação como pon to de referência no tempo. Por outro lado, os sedimentos são muito importantes, auxiliando o reconhecimento estudo das 
-struturas da região. Assim, as amplitudes o orientação de certos deslocamentos nas eruptivas puderam ser conhecidos, graças aos movimentos que interessaram os dois tipos de ro chas.

Foram também estudadas as rochas clásticas diretamente ligadas,quanto a origem,ao vulcanismo.São representadas por rochas piroclásticas propriamente ditas, isto 6 , por rochas expelidas por vulcões por brechas associadas as Intrusões alcalinas. Este Ultimo tipo compreende as rochas primariamente piroclásticas, Igneas, ou sedimentares, que sofreram "movimento, injeção, ou percolação de material Igneo. 0 estudo das brechas de importância capital para o conhecimento das condições geológicas que existiram na reg1ão. A figura 1, mostra um mapa da mesma, en que são representados os contactos das rochas alcalinas com a encaI xante, as rochas clásticas os pontos numerados de coleta ou material fragmentár1o englobado por rocha Ignea, das bre chas piroclásticas, isto 6 , provenientes da jeç̧ão depo sição de material vulcânico. Nêsse mapa, pode-se ter uma $\underline{i}$ deia do tamanho da área estudada.

araças beleza da paisagem, ao b́timo clima as propriedades medicinals das Gguas do planalto, serviu êle de chamariz a numerosos visitantes.

Derby, (16) no fim do stculo passado, foi o primeiro geblogo que examinou essa localidade. Esse notável naturalista teve sua atenção chamada para o arenito alf existente, extremémente branco, fino e fraturado, de aspecto meta mórfico. Relacionou-o a sedimentos carbonfferos,por ter on contrado, entre suas camadas, intercalações do folhelho. 
Contudo, não encontrou fossels que estabelecessem, correta mente, a Identidado dessas camades. Constatou Dexby, alnda, com referência ds rochas clastheas, tuio capoado por axtenito intrusoss alcalinas no sedirnento. Cunquenta anos dopois, novas observações sôbre essas rochas corem felters por Barbosa (3,p.33). Este autor situa os folhelhos, nas torrat Gős Istrada Nowa e Rio do Rastro, atribuindo o metamorisis mo de tals rochas influência da intrusão blealina ras ros mas. 0 arenito I identificado ao microsebplo por anuable atutor como Botucatu. Mads recentemente, temos o trabahno de Fredtas, (18, p.26-37), Incluindo os folhelhos ne serde pas 9a Dols, transgrassiva sôbre o arqueano na tregino de kocos de Caldas. Considera este autor o urenito cono pertencente 2 scril São Bento, transgrossivo malor ascala que os sew dimentos da serle antertor, anbos, em alguns pontos do planalto, mut to matanorfisados. Sugere, cono interpreteçäo da geologia um tnico vulcanismo soarguimento das estruturas sodimentares pelo magna alcalino, Gue as separou dasto modo, do embasamento eristalino. Em 1948, Barbosa, (44.3.235 237) aprosenta outro trabalho, contestando o ponto de vista de Fredtas, afirmando ter havido duas atividades do magma alenilino na região de poços de Caldas. O primeiro, plutônico anterior ao permiano, que depols de desgastado terid "ser. vido como base de deposição do sedimento. O segundo vulcânico, extrusivo, texia agido m virias fases, metemorfinando perturbando os arentitos folhelhos. Outras observa co๊es permitiram a autor cltado explicar a situaço eleqada dos arentos, por um processo de soergumento aprrogenneo moderno. Freltas $(29, p .85-90)$ volta ao assunto em 1951, rew futando as Ldelas de Barbosa, porêm não oferece nowos dados 
sôbre as rochas ciksticas. O Altino trabalho out se resere 2os masmos sadinentos o de Branco, am $1956(10,2.9-11)$. As -

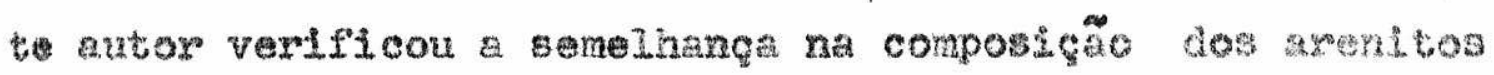

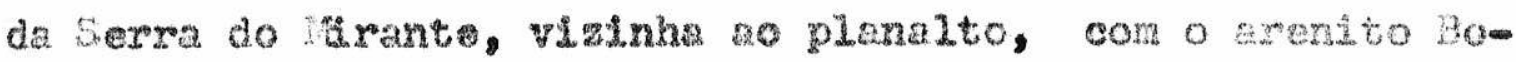
tucatu. Acha tamb\&m que os blocos de arenLto ruvinarem som Bre o magna, no plasalto, esposando a ideia de frostas. Com referencia as brechas estudou, do ponto de vista petrogréc -

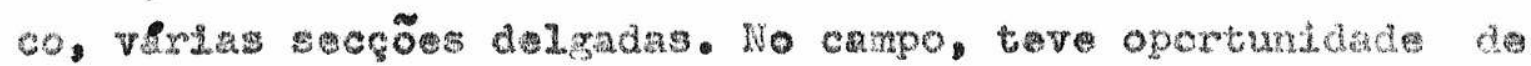
constatar Intrusōes alcm IInas, em aglonerado vulcânico,oosar

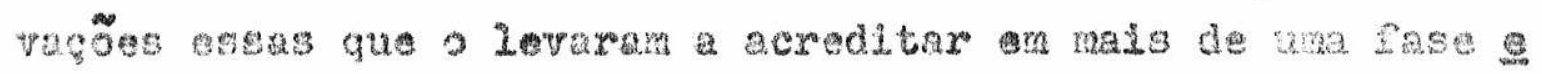
ruptions.

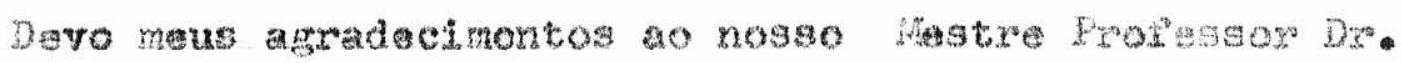

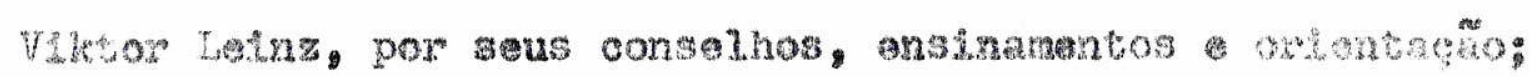
aos Dso. Alceu F. Barbosa e Rut 0. de Frejtas, nolo axpliso t8cnico aos meus cologas amigos Dr. Jose iloacir V. Gouti -

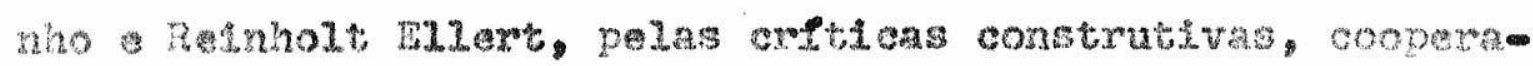

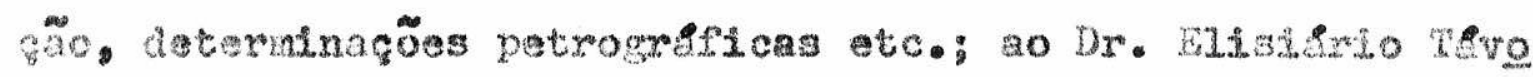

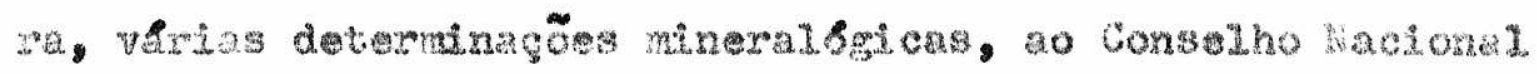

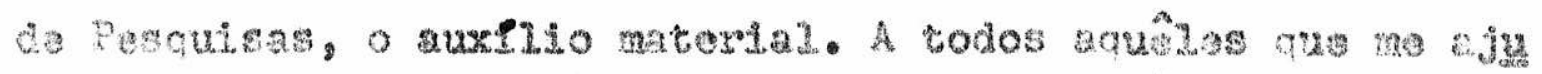
dexam, consigno os neus agradectmentos.

OBSFEVACOES:

AREXITOS E STLTITOS

Coleta de sedimentos: Procuramos colotar amostras de 30

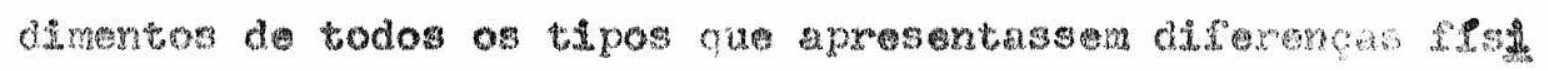
cas, Itrol6gleas de estrutura, que não tivessem solvido me

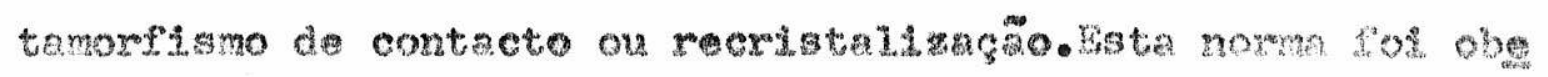
decàda pelas seguintes razöes:

a) As rochas gedimentares metamoridocing mostran srow

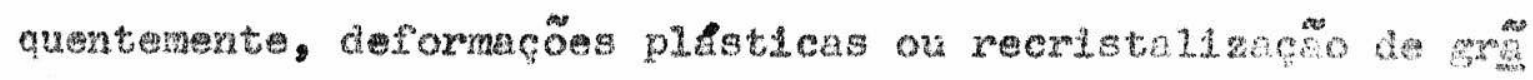
os, cujos greus de arredondanento são diferentes dos proser 
tados no sedimento original.

b) A dosagragą̃o das mesmas, para seren penct tredes, pro

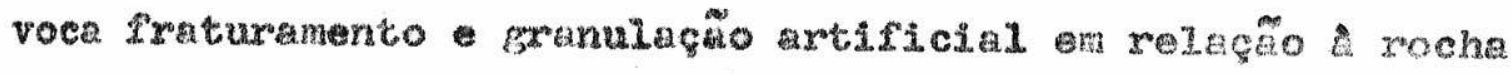
original.

c) Para facilitax a compareçẽo dêsto trabalho com os de outros autores. O estudo destas rochas metamoritates en sec

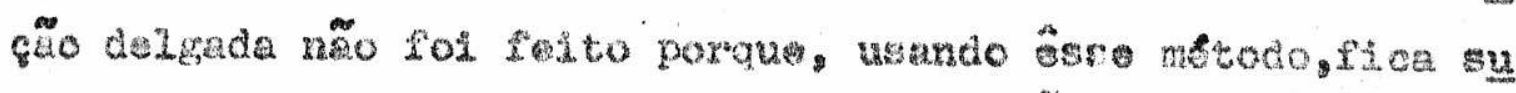
primida una dinenseno, resultando dal dados zmprecisos.

Lnaphe mecainica: Depois de coletado, o material fo desa gregado a räo. As Praçós de cada umostre, menores one $43 \mathrm{mi}$ crons, foram separadas por decantaçẽo. O moterial restante roi sacado on estufa a $100^{\circ} \mathrm{C}$ aproximadaments. Forem asmana

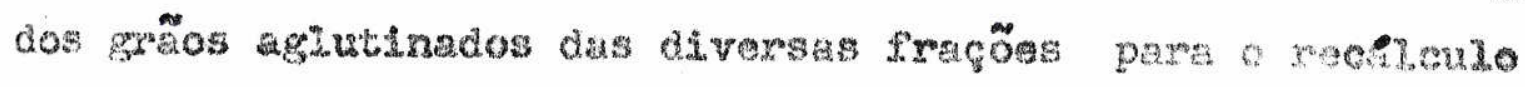
granulonetrico. Raxa são produzír um fraturamento artipicial

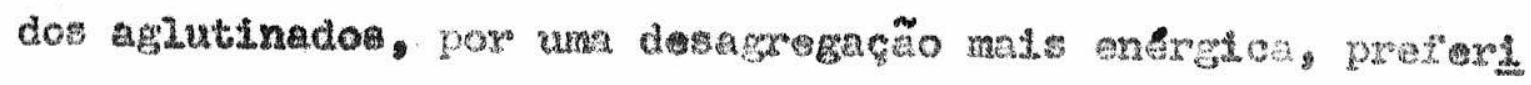

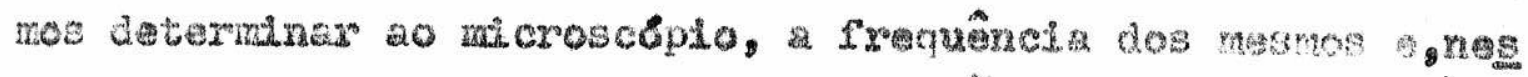
sa b2: ca do-siltito ou da fração fina do arento, for fasta pelo

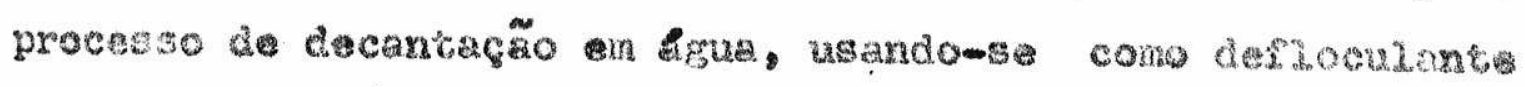
oxalato do sodio. A suspensão decantada fol filtruda o sau pâso detarminado, apss acagem om estufa. o metodo de decen-

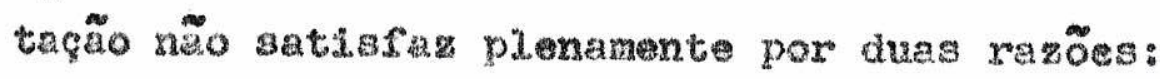

1w Particulas pequenas tâm wua marcha de qumda nommel modisjede no fludo, graças aos movimentos convaxionats do

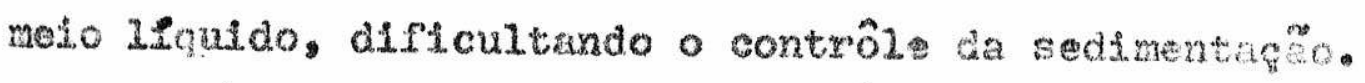

2- Outra raza o não saber se a desagregaç̄o fos anficlente para separax os compostos prinhrios do matrial. Entratanto, assim mesmo foi usado esse metodo, por ser suft. cienteranto aproximado para nẽo haver quebre do pxecessemento, que complicaria a marcha normel dos trabalhos de law 
boratorto. A anâlise mecânica dos sedimentos arenosos deu ti̊ pos diversos de curvas cumulativas, que foram representadas nas figuras $2,3,4,5$, 6. Nas abcissas, são marcados os di@ metros dos grãos milimetros. Nas ordenadas, a porcenta gem om pêso. nas curvas cumulativas, assim como nas tabolas que se seguem, são dados os nưmeros das amostras correspondentes à numeração do mapa da fig. I, nos pontos em que ram coletadis. As letras indicam os tipos diferentes de amos tras obtidas nos afloramentos indicados pelos numeros. Nanei re simples de resumir os resultados estatisticos dessa anali se está na obtenção dos quertis, mediana coeficientes de seleção. Os dois primeiros, $\mathrm{Q}_{3}$ Q $\mathrm{Q}_{1}$, podem ser obtidos, grificamente, como preconiza Krumbein e Sloss $(22, p .73), 0 \mathrm{~W}$ timo, pela seguinte formula: So $=\frac{0_{3}}{W_{1}}$. Na tabela 1 s so da dos os valôres da mediana, quartís e grau de seleção aproximedos das diferentes amostras. A mediana o coeficiente de seleção parecem dar indicações sôbre o processo de fiormação dos sedímentos clásticos. Como sè vê na tabela I, hế uma gran de diferença nos valôres das diferentes medianas. Quanto aos quartıs, hâ aproximação ora de um ora de outro, em relação a mediana das diversas amostras. Segundo Krumbein 1 Loss (22, p.75) êsses dados parecem indicar mudanças na competência do agente erosivo. Ainda segundo os mesmos autores, grandes dis crepâncias do grau de seleção devem indicar condiçōos variadas de transporte. Os dados texturais $Q_{3}$ o Ol $_{1}$ permitiram fazer una classificação de tôdas as amostras de acôrdo cora pet tijohn $(28, p .27)$. Segundo essa classificação, tabela $I_{\text {, as }}$ amostras $1 \mathrm{~b}, 4,6 \mathrm{~b}, 7 \mathrm{~b}$ - 10 poderiam ser chamadas de arenito siltoso; as amostras 5b, 7e e lob chamar-se-iam siltitos; a amostra 7 a seria un siltito argiloso o tôdas as restantes anostras enquadrar-se-iam entre os arenitos. 


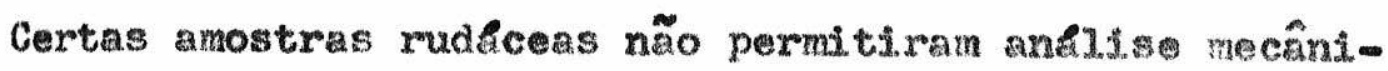
ca normal, pelo fato de conterem grandes ou paquenos fragmen tos de feldspato decomposto, ou rocha decomposta. Forta elas estudadas com auxflio da lupa binocular.

Forma dos componentes: As particulas componentes dos se dimentos foram classificadas, quanto a forma, segundo o grau de arredondamento. Esta uma rolaçäo entre a media dos ralos das angulosidades o raio do míximo circulo tnscrito. As soc ఢ̧ões dos grãos quartzosos das diversas amostras foram desenhadas por meio de "câmara clara" adaptada ao mícroscópio. se guindo-se metodo de Waddel (36), fot possivel fazer a determinação do grau de arredondamento para 40 grãos de cede fração. Tomando por base o princlpio de que o arredondamento de areias seixos auatzosos f função da diståncia transporte da, do tamanho dos elementos e do meio transportador, resolvemos comparar, na mesma rocha, os graus de arxedondemento dos grãos de duas fraçōes distintas, isto 474 a 105 a 297 a 500 microns. 0 mejo nẽo s6 influira no modo de deslocamento, como também no tipo de impacto que os grãos em transporte sofrerão. Assim, no meio aquoso, o transporte em suspensão facilitado pelo fato da sgua ter maior densidede que o ar ainda, por ter essa densidade aumentada, quando rica - impurezas tais como argila, ou sais. O impacto das particulas entre si amortecido no ambiento aquoso, devido ter a água maior viscosidad que o ar. Neste ultimo, o impacto $f$ direto, tanto das partfculas grosseiras cono finas. Na Lgua, as particulas pequenas, tendo sua densidade relatsva no moio diminuida arnortecidos os choques com os grểos vizinhos, po dem manter por musto tempo a sua superffcie original sem sofrer desgaste. Por outro lado, quanto malor a distâncla de transporte quanto mator a turbulência o movimento do malo, 
tanto maior sere a probabilidad de haver atrito entre os gre os. Dêsse rodo, em geral, quanto major o transporte, tanto maj

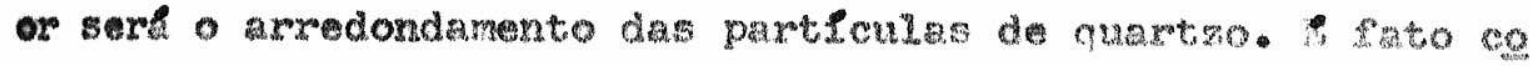
nhectdo que, on geral, nos fragrnentos movimentados nos ambien tes abreos ou aquosos, os maiores sẽo mals arredondados que os menores. Assim, pode-se determinar, às vêzes, o kren de ma turidade de certos sedimentos arenosos pela xelaçēo; temanho - arredondamento. Pode-se tambera determinar dentro de certos limites o ambiente que se fornou o sedimento, comparando os

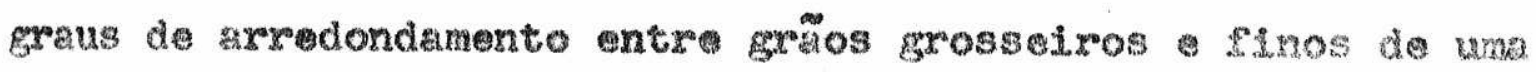
amostra. Con o fito de se estabelecer ssa comparsço, foram feltas as seguintes doterminaçoss do grau de arredondanento: dez de axenitos do planalto de poços do Caldas, unz do axrenito Botucatu (provalvelmente oblico), una do aramito Bauru, unz de sedimento considerado fluvio - glaclad, duas de currtgito não transportado, uma de grãos quartzosos de gnals decomposto não transportado. Og arentros Botucatu Bauru, Poram colotew dos en São Carlos (Estado de São Paulo). 0 gnats o uma das amostras de quartzito foram coletadas nos arredores de 5ão Fau 10. A outra amostra de quartzito fol coletada na Saras Jacobs na (Bahia). O arenito Itvio-glacial fos coletado en Campinas (Estato de Såo Paulo). A tabela 2 apresenta os resultados deg sa anblise. Foran foitas outrus determinaços do grou de axre dondamento em amostras do planalto de Hogos de Caldas, por\&m para estas se usou un mbtodo meis expedito, de Russel a Tay lor (30) modiftcado por lettijohn $(28, p .52-54)$, monos prociso. Er resumo os resultados desta iltime form os segurntes:

1- Lm cada amostra de roços de Caldas, nenhuma des dues fraçōes apresentou grẽos, cujas medias am gruน de arredonda mento ultrapassou o valor de 0,5 . 
2 Em geral, as mediss om grav de arredordamente comras

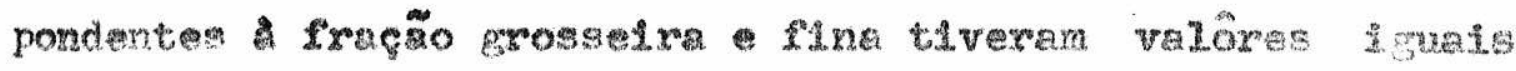
ov. meito profximos.

De tuto o que fol exposto, om conjunto, pode-se concluin que:

a) Fim ambiente provdvelmente ebu1co, ow graxs de arrew

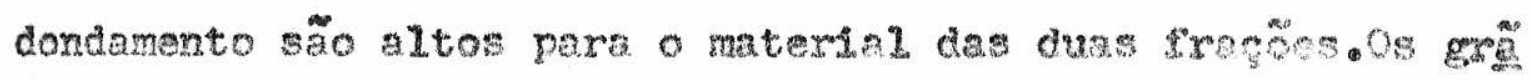
os de axala da fraç̃o grosseira são melhor arxadondados que os da fraço filna.

b) Em ambiente aquoso, os graus de axredordamento corm respondentes e de valôres próxinos entre si.

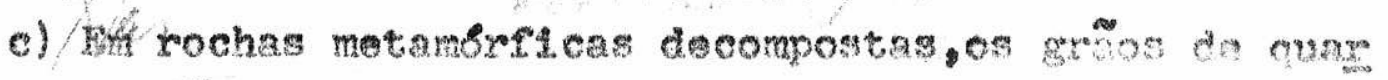
tzo apresontam nas duas frnçōes, grosselra fine, grous de arredondamento extremmente baxos os emeral, na frogito fi

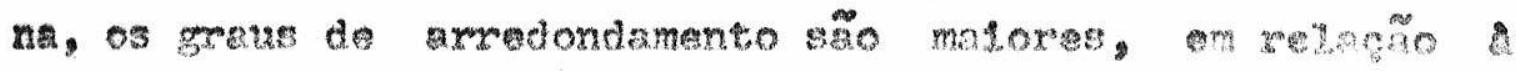
sraçe grossetra.

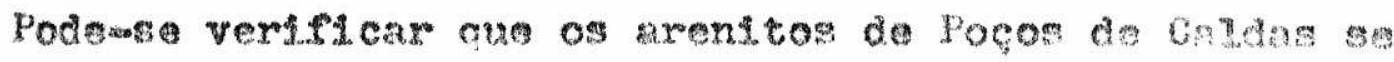
encuadran melhor entre os do grupo boisto \& entre os acuosos. Esse criterio; entrotanto, fos usado com cavtela pols arons. tos como os de Pocos de Gadas, provetwelment do oxsem misu

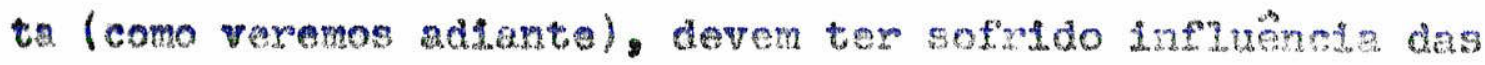
emptivas alcalinas, que modjficaram, en parte, o gros do ax* redondamento dos seus componentras.

Brliho: L o brilho um importante reio para se dictingulr grãos de arala trabejhados polo vento daguelos trobbhhados pela \&gua. Flzemos algemas determinaçős do britho usando a

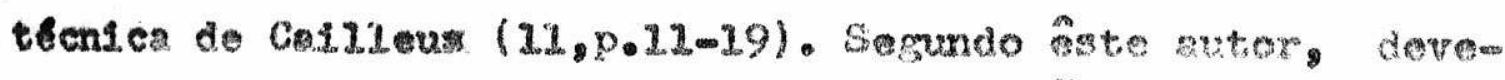

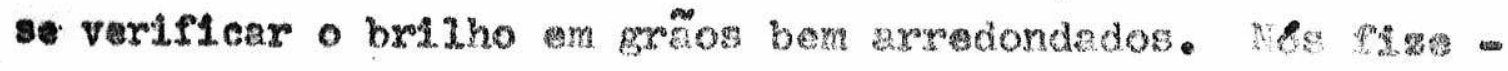
mos observaçōes não 36 nos grẽos de axeia arredondados como

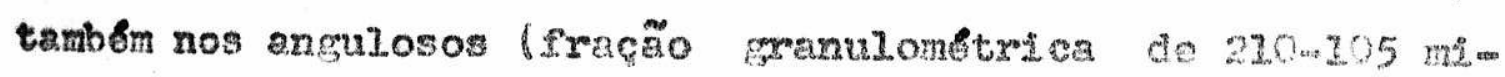
erons). 
As razōes foram as seguintes:

1-0 nosso sedimento arenoso nẽo mostrou grẽos de arela bem axredondados em quantidade suficiente. Como je fol visto antes nos resultados da determinação do grau de arredor damento, raxas form as medias superiores a 0,3 .

2-0 britho fosco, em grãos ben arredondedos, pode swr produzido por processo abrasivo, em vírude de tôda a super flcie do grão de arela estar exposta. Quando, por rom reentrâncias no grão de areia e essas reentrâncias apre sentaren brilho fosco, \& posstvel que êsse brilho se deva mais ao ataque de soluçōes que ao aprocesso abrasivo propprig mente dito. Nada impede, nessas circunstâncias, que grãos bem arredondados tenham tambem superffcie fosca provocada pelo ataque de soluções - não por xazões de abrasão. Considerando essas limitaçöes ao metodo, foi desnecessbria uma contagen porcentual do número de grãos brilhantes a foscos de cada amostra, no nosso caso. Algunas determinaçōes aproxImadas deram os seguintes resultados: para as arastres do grupo 1, 2 e 4 a maioria dos grểos de axeja foi do thpo bri Ihant. Os grãos de areia foscos dessas amostras mostraranse corroldos. Para as amostras $6 a$ - 10 foram encontradas quantidades aproximadamente iguais de foscos brilhentes . En tôdas as restantes amostras predorinou o numero de foscos em relação aos brilhantes. As amostras do grupo 7 mostraram malor quantidade de gräos bem axredondados foscos que tôdas as outras amostras. Fode-se dizer que, om conjunto as amostras de arenitos apresentaram malor quantidade de gre os foscos que brỉ hantes. Aquêles são do tỉpo corroido, prẹ ponderantemente.

Analise mineral6gica: Do material retido en cada penoira 
da anfilise gronulometrica, foram contados ao microsçpio 100 grãos oscolhidos ao acaso. Thm seguida, foram calculadas as med1as ponderais, de acôrdo con as proporções das porcerztagens, a partix destas, a composição mineralegica total. A tabela 3 mostra a composição percentual aproximada dos divar sos arenitos siltitos, excetuando-se os minerais pesados .

Mhnera1s pesados: 20 gramas de cada amostra dosagregada contendo tôdas as fraçōes granulonetrūcas corara atacedes por Lcido murifico, a quente. Im seguida, foram lavedas on igua - sêcas en estufa. Depois disso, foram lançades en bronof brmio afim de serem separado os mineraLs pesacos. Astes correspondem, an geral, a monos que $2 \%$ aproximacantante do pêso de cada amostra. Tôdas as amostras aprosentaram uma bo: porcentagen de airconita (vicie tabela $4_{4}$ ).0 minimo observado fol

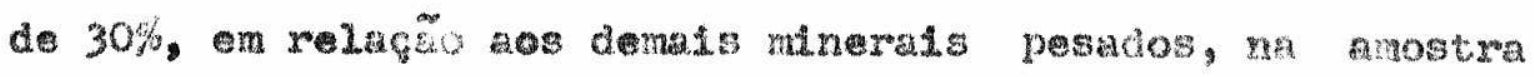
$10 \mathrm{~b}$.

Fin resumo, as anostras $7,8,9$ e 10 possuem major vrablab lldade de minerals pesados. Nestas amostras ocorye tambsin leu coxênto en certa quantidade. Os minerajs opecos não foran diagnosticaidos, por dificuldades tenicas na sue detorninaçฉ̃o.

Ea tôdas as amostras, ocorro o minerel baueritte, ora na fração Leve, ora na Pração pesida. Por causa dessa propriodade, não entrou no cômputo entre os minerals poscdos porpriamente ditos. A bauerita parece ser o resultacio dia lixi viação de biotita. L Isbtropa ao miteroscbito. Em certos pontos dêt mineral, aparecem aglomerados microcristolinos de quartze. Segundo Bremma I Harwood $(9, p .20-26)$, a biot, ta sub

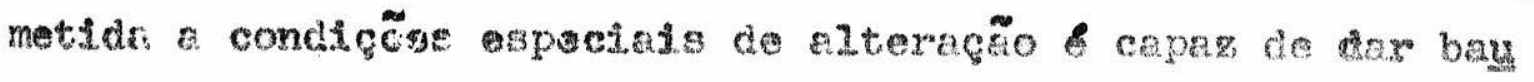
orita o residuo contendo tม́tânio. 
o anatásio apareceu sempre Ideomorfo, frecuentenerte formando agregados minerals, que servern algumas vêses com mo cimento aos grãos de quartzo. Suas caracteristicas Indicam autjenta.

A zirconita, em geral ber arredondada: apsestartou frequentemente tons roseos e tongamento midio de 0,2 miIfmetros; quando prismatica, mostrou froguentemente texminaçoo em pirâmides altas.

A turmalina foi encontrada empre bem exredontada de côr castanha, parã, ou azulada, con inclusõos raras.

0 rut1lio apresentou sempro forma prismetice aryocion dada côr Iaranja avermelhada a amara lada.

A monarita foi encontrada em quantidado na amostra 5a. Apresentou-se, no caso, com taminho nédio de 0.5 mil metros ben arradondada.

A granada mostrou-se incolor na majoria das pênes.

o corindon, aul caractex Ltico apresentovwe Às vêzes arredondado.

A homblenda a apatita form determinadas prockra mente, por texem sido encontradas em fragnentos nut to peguscos.

Letruturas sedimentares singenet cas e epigengtiess:0s

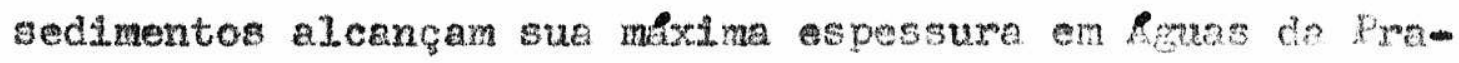
ta a norte de Andradas, na fazenda Pinhoirinho, poucos cuilonetros desta cldado. Nesses Locais a cemov em pri

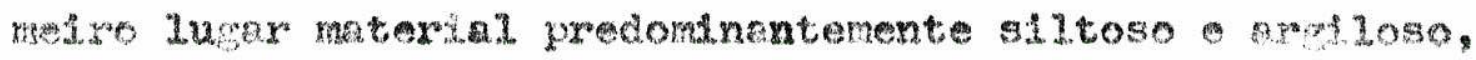
om conjunto, com espessura aproximada de 60 metros. Acima dassa camaca mixta, aparece arent to com aproximadamento 30 notros de capossura. Mos outros pontos do planaten. foram ancontrados ind camente arenjtos. Cuando sobrepostos, pa 
rece não haver inconformidade entre o sedimento sthtosomar giloso o arenoso. São frequentes leitos finos e espessos de axentito intercalados no siltito argilito. Ocoryen tan bern, neste sedimento, leitos de muscovita bauerita, cujes plequetas atingen, em casos raros, um centinetro de tama who e leitos do seixos de gnals ou crent to de tam no maxi wo de alguns centimtros. O matorial fino apresentou acama aento Laminax paralelo e retrico c, quando inclincdo, on ân grilos de mergulho não sẽo majores que 200 . O arenito apresente ostratificação plena paralela, ou cruzecta, na grande majoria dos casos. A estretificação cruada, no nexino, em angulos de $30^{\circ}$. Na Serra do itixante ocorre sedimento areom siano imsturo om tipo de depsito torrencial, Laheo (24.,p. 83). de cuja textura damos um escuema na ligura 7.2 : fre quente encontrax nos arenitos, que afloran na serre do Mrante, brecha intraformacional de argilito ou arenito pi no e concentraçoes limoniticas. Devern ser resultantes do dissecanento de material argiloso, que foi, posterionmen te depositado con o outro sodimento. Na serrs do quartel, a Na de Aguas da Preta, existe pedredra de arenito gilicificadio, onde se encontram nodulos esferoides, assenelhan do-se bastante aos do arenito Botucatu encontrados ne es trada de rodagem, entre Analândia e Descalvado, nas encos-

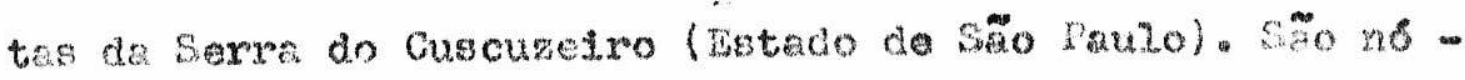

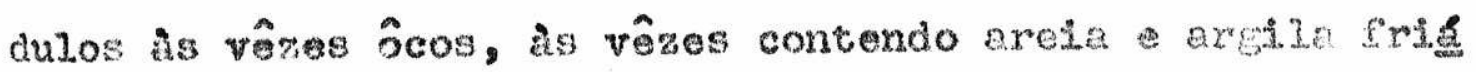
veis, outras vêres compactos at o centro. Arrescrutrm senm pre camadas concêntricas discerniveis oxa por sua meior concentraça de caicedonea, or por mior concentracto for ruginosa ou manganosa.

Não foram encontrados ats o momonto, sedinontos serae 
Thantes aos estudados fora da Área das intrusōes alcalinas. Os mals proximos ocorrem om aflorsmentos descontinuos, na Serra do Mrante. Apoian-se sôbre o gnais. No sou ponto mais alto ( 1580 metros aproximadamente) êstes sedimentos parecem estar ligeiramente basculados para W. Provavelmente, al tambem ocorrem rochas alcalinas, pelo fato do talus da mesma serra, na eltitude de 1500 metros, conter blocos de tinguaito, de mistura com os de arenito. Para o sul, des creve esta serra uma ligelra curvatura para $E$, acompanhando externamente a Serra do Paiol, terminando em Rguas da Prata a 800 metros de altitude. 0 arenito capeia estas ele vaçōes, cujas cristas passam gradualmente da cota 800 a 1580 metros. Suas diaclases sẽo aproximadamente EW - NS obedecendo as linhas de fraqueza do cristalino. Em Aguas da Prata ao norte de Andradas, aparecem nestes sedimentos I númeras perturbaçōes estmuturais (falhamentos, basculamentos etc.). Dificilmente são observados ademamentos de blo $\cos$ em ângulo superior a $10^{\circ}$. São conatatadas Inúmeras intrusōes alcalinas nos arenttos de região. Diques radiais, em relação a centro do planalto são frequentes nas pedrel. ras de arenito próximas a barragen do R1o das Antas ate Po ços de Caldas. Em vista aerea tem-se a clara impressão de que os afloramentos de arenito seguem uma Iinha interrompi. da no longo da borda do planalto, acompanhando-a, cono incrustaç̃o interna das encostas montanhosas do grande cfrcu 10. Freitas (3, p.37) jk havia folto observaçōes somelhantes. A posição dos mesmos varia entre cota de 1000 metros ate a cota de 1500 metros, mergulhando geralmente pare o interior. 
tos por n6s estudados, vide figura 7, além de apresentarem textura "turbilhonar" possuem certa quantidade de feldspato, microclina om geral, tambern constatada por Branco (10, p.9), que por decomposição dá a rocha um aspecto salpicado. Esse sedimento arcosiano apresenta acamamento do tipo torrencial, isto 6 , alternância de camadas horizontais parale 1 s com estratos cruzados ou cabticos, ou ainda alternân cla de camadas paralelas grosselras - finas. Segundo varios autores, Twenhoffel (34,p.313), Krynine (23,p.353-363), - presença de feldspato nos arenitos dêsse tipo indica decomposição retirada sem complota destruição dos minerais, erosão raplda, pouco transporte soterramento em curto es paço de tempo. O tipo de acamamento irregular sugere, por outro lado, variações de competêncla durante o processo do sedimentação. Outros dados, que apontam condições variadas de sedimentação, são as alternânclas de arenito siltito em Aguas da Prata a Norte de Andradas. Estes arenitos, intercalados no silt1to, possuem notáveis sernelhanças com os domais arenitos da mesma região (incluindo o arenito, que ocorre acima do siltito, em espêssa camada). Têm o mes mo grau de seleção, mediana granulométrica sempre "na fraçẽo arenosa, estratificação em geral cruzada etc..Hล casos excepeionals, como por exemplo nas proximidades da Cachoei ra do Ozório, em que o arenito apresenta estratificaçõo in clinada curta e curva, ou ainda, niveis de seixos areia grosseira, indicando, possivelmente, locais onde agiram cor rentes aquosas. Normalmente o siltito mostra laminação, pro durida possivelmente en condições celmas. Como jâ fol dito anteriormente, existem leftos de mica no siltito, cujos fragmentos, as vêzes, alcançam um centimetro de tamanho.Tal vez seja êsse o indlcio de proximidade da fonte, ou condIções calmes de sedimentação, Krumbein e Sloss (16), pois 
com o transporte, a mica se fragmenta, diminuindo de tama nho. Como se pode depreender das curvas cumulativas, $0 \mathrm{sil}$ tito nem sempre se apresenta ben selecionado, talvez por defeito de amostragem.

Origem a ambiente de sedimentacão: Cabe aqui fazermos uma consideração de carater tebrico. Para tanto empre gamos o cálculo proposicional, que permite traduzir a lin guagem comum em simbolos operáveis matemdicamente assim, orlentar o raciocinio para obtenção de conclusões em moldes simples e precisos. Fxemplifiquemos numericamen te para esclarecer o método, usando modêlo de Reichenbach (29): "Jogando dols dados, um homem faz a seguinte aposta- "Eu obterei a face quatro um dado ou no outro". Se substituirmos a proposição "Eu obterei a face quatro em um dado" por "a" so substituirmos a proposição "eu obte rel a face quatro no outro dado" por "b" a, ainda, a operação "ou" por "v", tôda a proposição será expressa simbo Iicamente pox "a $v$ b". Esta litima expressão equivalo d expressão seguinte: "a $\mathbf{v}$. agebra comum, "v" Indica operação de soma "." a de mul t1pl1cação. Dêsse modo, substituindo essas proposições pe las respectivas probabilidades expressas em números, tere mos para $a=1 / 6, b=1 / 6, \bar{a}=5 / 6$, o seguinte resultado: $1 / 64$ $+(5 / 6.1 / 6)=11 / 36$. Bsse raciocinto mostra que, para se obter uma face determinada en un dado, a probabilidade se rá de 1/6. Para um dado ou outro, será de 11/36. Para wai dado ou outro, ou ainda outro, sera de 91/216. Nota-se ha var, portanto, un aunento de probabilidade com aumento dos têrmos da expressão. Por outro lado a probabilidade de ter-se uma determinada face em un dado outro seré del/6. $.1 / 6=1 / 36$, en um dado outro ainda outro, sexé de 
1/216. Ha,portanto, uma diminuição de probabilidade con au mento dos fatôres.Voltando para o camo da geologla, agora podemos traduzir a proposição geral: "o sedimento estudado provén originalment de sedimento fluvial, ou de sedirnento lacustre, ou alnda, de sedimento marinho "pela seguinte formula simbolica": "a $\vee$ b $\vee c^{n}$. Se atribuirmos certo grau de probabilidade a cada termo da fórrala, verificamos que a soma dos mesmos representa um aumento de probabilidade total, como no caso numérico. Por outro lado, se representarmos por simbolos a proposição geral: "Ocorre no mesmo pa cote de sedimentos, siltito formado em certas condiçõos e arenttos en outras condições arenito grosseiro arcosiano em condições ainda diferentes das dues primeiras", veremos: "A.B.C.". Se atribuirmos certo grau de probabilidade a cada um dos fatôres, vemos que hé uma diminuiçẽo da mesma na oxpressão acıma, em relação a cada fator om separado, por se tratar de um produto. Podemos concluir que, do ponto de vista teórico:

1- 0 sedimento estudado deve ter diversas procedências.

2-Este sedirento diffeil de ser encontrado,por terse sedimentado, provàvelmente, m diferentes condiçōes de ambiente.

S6 ha valor na teorla quando esta encontra confirma ção no campo prático. Dêsse modo, estudando os mineraĹs pesados, pudemos constatar serem êstes comuns de rochas ácidas. Assim, a zirconita monazita têm sua orł gen en rochas Igneas acidas ou intermediárias, 0 mesmo podendo- se dizer do anatasio, que geralmente autgeno por decomposi ção de 1lmenita ou mineral titanffero. Miner $(27, \mathrm{p} \cdot 235)$. 
A côr rosada da zirconita, no caso, 1rideio de Ldam de arqueana, Saldanha Franco $(17,0.48)$. Os kasnerals pasa dos: turmalina, rutilo, granade córindon provân de rochas metamorificas ou Lgneas Acidas. Os selxos fragmontos encontrados nos arenttos siltitos de Rguas da. Preta são do gnais ou de arenito cimentado por limonita. Os matrerais pesados do selxo de axent to apresentam $90 \%$ aproximadanento, de turmalina pecuena porcentagem de zirconita; de mo do que, não houve confirmaçẽo da primeira hipót t1ca. Quanto A segunda, sabersos que, at asorn, nẽo \& ar contrado êsse mesmo tipo de sedimento om outras pertes, a nẽo ser dentro do planalto de Poços de Caldas ou junto a ใ̂le, na Serra do Mixanto. Podemos admitir ques, so todo o pacot: sedimentar mostra alternência de rochas formadss em

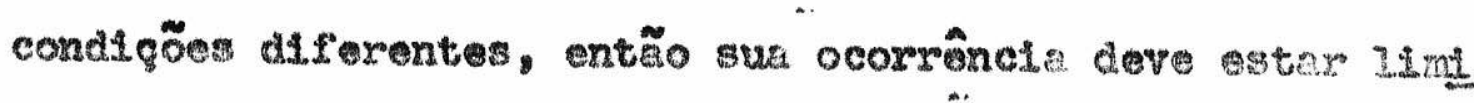
tada a une linha de sobreposiçæo de moios ambientes diversos de sedimentação. Tal situação, por exemplo, poderia existir na beira de deserto. o sil.tito argilito deposi. tar-se-1 ser expllcadas como transgressóes passageiras de arei.es do deserto que, por $\mathrm{flm}$, cievam tar sobrepujado os depsstos

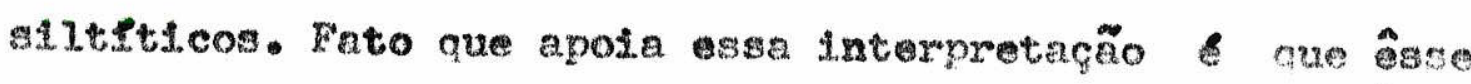
tipo de sedimento existe "playas" atuais, Haxilton (21), apresentando espessuras senelhantes is por n6s encontredas, - mesmo acontecendo ex desertos do passado, Martin e frorn (26,p.88). Estudos de Barrel $(5, p \cdot 285-294)$ nostrom serem comuns zonas f́rtdas ou semi-aridas sedimentos dêsse thpo. He declive suficiente para que, am um caso de chura in tensa, as torrentes carregadas de lama tronsporten os dew tritos a se espralem na planfcle de inundação. Essas super. 
Ifcles, on climas áridos, são esterreis durante quese todo o ano. Detritos depositados pola śgue podem ser ficilrenta re trabalnados pelo vento, de modo que, nesses locais, he jus-

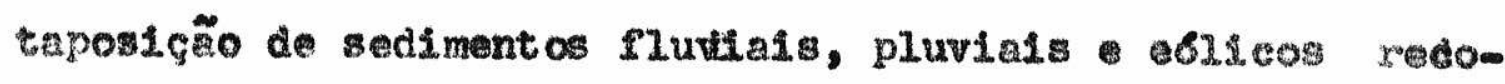
nheclvel.s por sua estrutura. As camadas argilosas podem recchar so secar, dando fragmentos que podem ser movimentados pelo vento. Fragmentos de arenito ou gnais, no nosso caso, podom ser retomados de depósitos piemônticos levados pela Ggua duxante seu movimento, formando lestos de seixos. A rea çẽo sijtftนca arenosa, incoerente quando sêca, Iovada polo vento a grandes distânclas. Pode tambên sicar retida diante de anteparo montanhoso, que dissipa a competêncla ob lica. Originar-se-1a, assim, a brecha intraformecional j\& citada, encontrada na Sorra do isranto.

Idade dos Arenttos: Ate agora nenhum fossil fol verificado nos sedimentos arenosos considerados. Nessas condi-

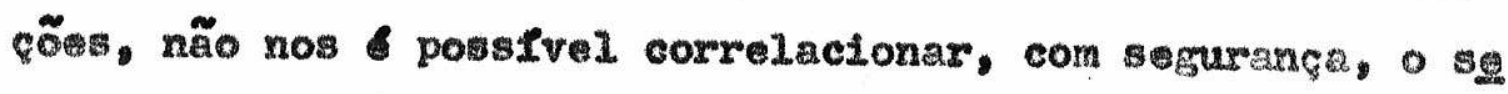
dimento a outros nem datí-10. Faremos uso ontão die caracteres 21tolbgicos, para podermos compara-lo a outros. Quen examinar pela primeira vez os arentios do planalto do poços de Caldas fica logo sugestionado pelo seu aspecto frifvel a pela angulosidade dos gxãos que o compõem. Derby (16), o pri meiro geblogo a encarar êsse assunto, acreditou inicialmente na possibilidade de se tratar de quartzito do embasamento cristalino. Logo abandonou essa Idela, atribuindo Idede carbonffera ao sedimento, pelo fato de ter encontrado nelo intercalações de folhelho.A primeira vista, parece realmento un quartzito. Entretanto, as andises de arredondamento, tablia 2, parecom indicar não terem êles sofrido matamor fismo suflciente para se transformexem tal rocha, cujos 
grãos teriam angulosidade multo maior. A segunda idela de erby encontra melhor apôio nos resultados sedinnentologicos. Voltando a tabela 2, pode-se notar que o grau de axredondamento dos arentitos de Poços de Caldas, semelhonte aos dos arentos fluviais e Rlúviomlacials am geral. A tetulo de comparaçẽo, damos, a seguir, os coeficientes de seleç๊o de

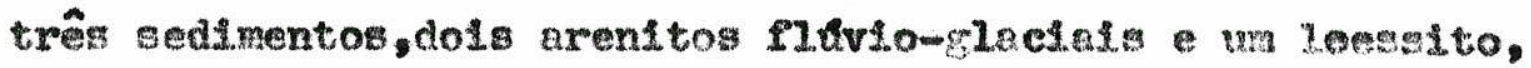
cujos histogramas form obtidos por J.einz $(25, p \cdot 17-24)$. Por êsses dadog vertflcuxnos que o arenito de Pltanga fEstado de São Paulo) e o loessito de flio do Sul. (Sante Caterina) são ben selecionedon com coeficiente de seleção ao redor de 2. 0 arenito Iino do Rlo do Sul, ao contrkrlo, deu seleg̃̃o nediocre no redor de 10. Os dols primeiros, entretanto, mostren como o sedinento giaclal retrabalhado pode apresenterase bem selectonado, perfeftanente compartivel aos de pocos de Caldas. Existe, no entanto, forte discrepância coz relação cos minerads pestados. Enquanto os sedimentos glaciads on flivic-gileclels contêr de modo unjforme a granade, predortinentemente. hevendo tambem cexta frequência de turvaline apotita, leinz (25.p.27-28); nos nossos sedimentos, a granada e e epetita ga parecen om porcentagen muto baixa. Sste ditimo dado arasta a hipbtese de Derby de que ps arenttos por êle encontrelos. proximos dentro do planalto de Poços de Celdes, sejnn correlrcionfrels noss edmentos fluvio-glactals.

Como vimos na introduçẽo dêste trabalho, os evtores maL̆s modornos apontam semelhanças dos arentos constderados, com - arensto Botucetu, principalmente devido ao conteudo col L 1 dspato quase sempre presente em sua composicão. Forra então comparados os nossos dados, aos obtidos por Carvatho (22) en estuclos reatizedow sôbre o arentito Botucatu no Instedo de são 
Paulo tamberm aos de outros autores. Pode-se dizer que , apesar de nossos arenitos apresentarm bom grau de sele -

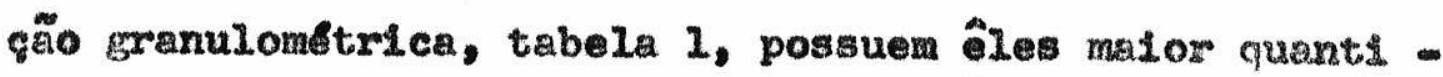
dade de axgila do que os arenitos estudados por Carva tho (12). Esta autora, comparando o arenito Botucatu a areisas desérticas da ffrica, verificou que há am ambos, de um 180 do geral:

1- Multo material bem selecior ado para a granulaçēo de 500 - 200 microns, chegando a representar $96 \%$ da amog tra.

2- Muito pouco material mais rino mals grosso que a moda.

Os nossos histogramas, obtidos a partir das curvas cumlativas, mostram que a moda se situa no intervalo de 500 a 125 microns, gerral mais próxima a êste Ultimo vaIor em porcentagem aproximadamente de $45^{\prime \prime}$ em relação ao total. Aclma abaixo da moda se distribue o restanto ma terial correspondente a $65 \%$ da amostra.Como sอ จิติ,nẽo ha perfecta correspondêncla entre os dados daquela autor» os nossos.Bagnold, $(1, p .118-124)$ teve oportunidade de vert flicar que a estratificação dos sedimentos eblicos mostra haver mudanças rapidas nas condiçōes de formação dêsaตs

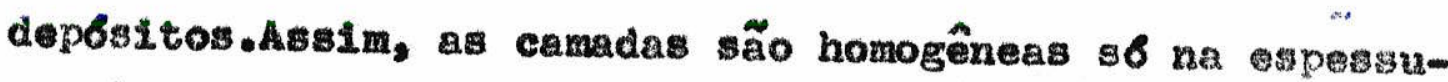
ra de poucos millmetros.Amostragen em malor aspossura faz com que.junto a moda, aparega uma outra classe de grenulaçēo,que a acompanha om porcentagem.Assim,por amostragera mal relta, pod-se modificar totalmente a curva cumulativa dando-Ihe caracteristicas de pequeno grau de seleção.Alnda maiores discrepâncias na granulometria são obtidas, ouan do uma duna so move, havendo mistura de duas caradas, urna gros 
selra - uma fina, formando depósito misto. Dêsse modo, seja por falhas de amostragem ou outra razão, não ha correspon dência grenulometrica entre os arenitos por nós estudedos a - arensto Botucatu. Quanto ao grau de arredondamento, os arenitos de Pogos de Caldas apresentam gräos em médla pouco arredondados, como vimos anteriormente, nāo sర nas fraçōes Iinas, como nas grosselras, tabela 2. Isto, segundo Twenhof Pal (34.p.308-309) não \& suficiente para que se elindne a hipotese do sedimento om questão ter sofrido transpoxte eb11co. DLz aquêle autor que pequeno transporte, ou ainda a retomada do sedimento por outro agente, pode modificar o ar redondamento orlginal dos componentes. De qualquer forma, o axredondamento no caso não 6 do tipo eb11co, enquadrando-se melhor entre os do tipo aquoso, tabela 2. Comparando os nos sos sedimentos, de grau de arredondamento ao redor de 0,4 , no maximo, com os de Carvalho, no maximo ao redor de 0,7, vê-se que os nossos são completamente diferentes daqueles . Quanto ao brilho, ja vimos antes que o gräo fosco $\$ 6$ pode ser determinado quando bem arredondado, o que não 0 caso. Dessa forma, nẽo - possIvel estabelecex comparação con ou tros arenstos, quanto a êsse caratex, que pode tambem surgix em clrcunstânclas outra que em ambiente e61ico.0s minerais pesados serviram de base mal: segura para estabelectmento de smelhanças entre as duas formaçōes. O arenito Botucatu descrito por Carvalho (12) apresenta, alem dos minerais por nos encontrados, ainda: baritina, epidoto estaurolita. faltando a Elle anatásio, comm nos de Poços de Caldas. Entre tanto, podemos dizer que ambos divexgem pouco, principal mente se considerarmos a grande distância do local on - 
de foram obtidas as amostras estudadas por aquela autore (a NW do Estado de Sẽo Paulo, quase nos limites com o kstado do Parane) em relação aos de Poços de Caldas. pos\$Ivel mesmo provarel que haja uma carta somelhança do alguns arenttos de Pogos de Caldas com os da serle Beuru, pots têm comum o amblent aquoso de sedimentação. Interessante comparar alguns dados nossos com os de Freltas (20) sôbre a serile Bauru. Ja se nota flagrante diferença na composição dos dols arenttos. Para os da serrie Bauru, - toor de argila es mito mator, Frestas $(20, p .80-81)$ do que nos nossos arenitos (figuras 2,3,4,5 6). For outro lado, diz Freitas no seu trabalho, qu os sedimentos por île estudados apresentan grende variabllidade dos coeficientes de seleç̃o, geralmente medfocres, o que nẽo \& 0 nosso caso, tabela 1. Os arenitos por nos ostudados possuem, frequentemente, teor mais alto en quartzo, superior ao maximo (85\%) dos sedimentos estudados por Freltas. Alsm

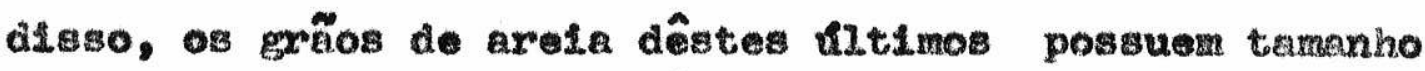
maximo de 0,125 milimetros, ultrapassado pelo tameano me dio dos componentes dos arenttos de Poços de Caldas, con valores ao redor de 0,3 milfmetros. Por outro lado,o teor en zirconita dos arenitos da série Bauru sem pro buixo, em contraste con os minera1s pesados dos arens tos de Poços de Caldas. Aquêles año tamben comung de xochas metambrficas de rochas basfiticas, contrastando com êstes, conuns de rochas Igneas źcidas. São ambos semelhan tes, quanto vo grau de arredondamento, tabola 2 , entrotan to como je fol dito como veremos adiante, o arenito de Poços de Caldes parece ter sofrido a Influência do magma alcelino que parece ter-ihe modificado em parte o grea de 
arredondamento dos componentes. Além disso, m aguas da Prata 20 norte de Andradas, existe diabásio cortando os axenitos. Fica assim eliminada a hipotese de, pelo menos êstes, serem da sérle Bauru. Delxamos de comparar os siltitos que ocorrem abaixo da ultima intercalação de areñto com outras formações sedimentares, porque sômente as camadas superiores ocorrem en tôda a Area estudada Irtorviteram nos processos vuleânicos. Conslderando as analo glas do arenito quw ocorre na ragião de Poços de Caidas (1ncluindo o espêsso pacote de Intercalaçóes aronosas no siltito) com as rochas da formação Botucatu, a corrolaçäo com tal arenito aceita por n\&s, provisoriamente. 0 arenito Botucatu fas parte da série São Bento acha-se ex Aguas da Prata cortado por sill de diabásio da mesma se rie. Atribui-se-Ihe Idade supostamente trielssica sua si tuação estratigrefica não fol elucidada dofinitivament . 1 bers provável que êste arenito tenha so depositado, ou te nha sldo remoblilizado durante as manfestaços alcalinas vulcânıcas, polis apaxece capeando lava ou tufo nas proximidados de Aguas da Prata, no leito e margens do C6rrogo do Quartel, Darby (26), mais ao nort na fazanda Nionte Alto intercalado com tufo. Fiol impossivel determinar o $\mathrm{cg}$ ráter da rocha alcalina decomposta - o tipo de contacto, por Inlta de melhores exposif̧ōes. Eim todo caso, o arenito ostá cortado en contacto a quente com o tingualto, na ma Lorla dos outtos afloramentos, fazendo-nos acreditar que 6ิLo se depositou antos das intrusões alcalinas maniente misto oblico-aquoso. Se a situação dêsse material no tempo aroblamética, por outro lado a sua situação aspacial de gxande importância para stabelecex os İenôm- 
nos estruturais da regiẽo.

AS BRECHAS

Descricão: Entendemos por brecha, tendo por finalidade o mapeamento geol6gico, a rocha fragmentarcia ligada diretamente ao vulcanismo alcalino. Como se pode ver na figurs I, as brechas aparecem frequentemente acompanhando os afloramentos de arenito en linha bordejante interna do circulo alcalino. Ha excęõss, quanto aos dois afloramentos, que ocorren no centro sul do planalto. São descritos os auatro tipos seguin tes:

1- Brecha de côr castanho-arroxeada encontrada nas proximidadesdda reprêsa do R1o das Antas ate Aguas da Prata, se guindo a estrada de rodagem, que liga aquela cidade a Poços de Caldas, ao norte de Andradas em pequeno afloremento na fazenda Pinhelrinho. Os afloramentos aparecem descontinuos, como se pode ver na figura 1 no anexo mapa teolbgico da re glão. No planalto, essa brecha se encontra geralmente decomposta e, então, s6 reconhecivel pelo fato de os fragmentos que compõem mostrarem côr clara, que sobressai na massa escura castanha da natriz. De Cascata a Rguas da Preta, estas rochas estão mais frescas.

a- Matriz: 0 exame macroscópico revela a existência de una matriz de côr tipicamente castanho-arroxeada, que", decom posta, parece-se muito com a terra roxa proveniente das rochas básicas. I de granulação flna afanfitica, s6 se podendo distinguir o quartzo que aparece on grãos detrlticos arredon dados. De Cascata para Rguas da Prata, hâ um aumento de quar tzo detritico na matriz. o examo microscbpico mostra: em pri melro lugar, o alto teor om claclta. Esta so encontra, as vệ zes formando agrupamentos de cristals grandes de geminagão 
encurvada. Wa maioria das vêzes, entretanto, forma mase de microcristais, que compõo o cimento ocupam, substitusçẽo, os paços dalxados por mexais, tanto da matriz cono dos Iragmentos. Tel s sua quantitade que, acreditamos, deva talvez entrar en porcentagem superior a 60 no feltro dessas roches. Ao lado da calcita existo tamber grande quantidade de hematita. Lla responsével pela coloração dessas rochas, aparecendo microcrtstalina, castanho-avermelhada opaca. A

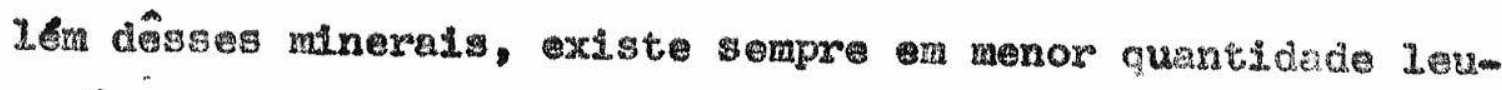
coxênio massa fina, intersticial. A hematita aparece, fre quenterante, formendo uma rede irregular, onde a calelta os frragmentos estão incluidos. As massas de cristais inos

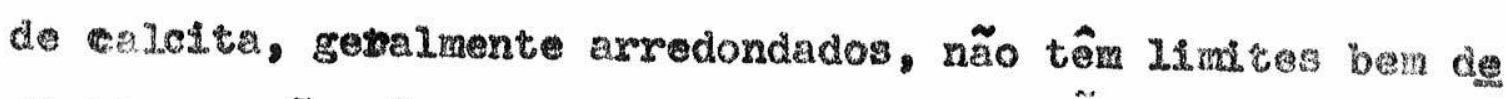
finidos - nẽo são zalores que algurs milinetros. No caso do apresentarem linttes nitidos, com relação a hematita o demais minerajs, são por nós considerados como fregmentos não mas: como matriz.

b- Iragmentos: Os fragmentos sẽo de kols tipos prơn clpais: os fragmentos de rochas os fragmentos de minerals.

Os fragrantos de rocha, macrosedplcamente, são de dois tipos. Os fragmentos claros, esbranquiçados, de textura gros selre geral os fragnentos escuros, castanhos de textura erer linent f'ina, arenftica. Os primeiros são isentos de quex tyo, podendo-se distinguir, mesmo meroscopicamente, ripas de Seldspato que alcançara, no máximo, alguns mithetros do comprimento tambern pontos asverdeados, ond houve cloriti mação. Os Iragnentos escuros sẽo, frequøntement, pouco nltidos, realęando-se mal na matriz, cuja côs samelhanto, tạ bsm ascure castanha. Ambos os tipos sčo angulosos, alcen Garrdo aquêles, on gexa1, major tamanho. 0 malor oncontzacio fol de pouco mals de uma dezena de centimetros. Bntro os mi- 
nerais, o inico que se pôde determinar macroseoptcamente, como vimos, o quartzo, que aparece em relação aos cutros, en tamanho maior. Este, assim como grãos detriticos de felds pato, a microsebplo, ressaltam na massa. Sua quantidade aumenta de tal modo nas proximldades de Rguas da Prata que chegam a formar um arenito de composição igual a $80 \%$ em rela ção matriz, que, no caso, fica reduzida a simples cimento. Alem do feldspato do quartzo, existem sempre pequenas porcentagens de grãos de apatita, ora prismaticos bem ideomorfos, ore fraturados, pequenos fragmentos de magnetita ou ilmenita. A proporçẽo maxima de quartzo obtida om ralaçẽo ao feldspato fol de 90\%. Este ultimo se identifica em dois tipos: ortocle sio albita, quase em Iguais proporçōes, havendo, en certos casos, predominância do primeiro. Os fragmentos claros, ao microscbplo se revelam como sendo principalnente de rocha, cuja textura composição se assemelham.ao diabásio. Apresen tam xipas finas de plagioclasio, cujo tamanho máximo observa do fol 3,5 milimetros de comprimento, para 0,3 milimetros de largura, dispostos Irregularmente. 0 espaço entre as ripas ocupado por calcita agregados alongados de magnetita ou 1.1 mentta. Csses fragmentos estão bastante decompostos; porém . fol possfvel diagnosticar o feldspato como sendo albita com Indice menor que o balsamo ângulo de extinção para os gemi nados, segundo a lel da albita so redor de $14^{2}$. Ao norte de Andradas, aparece assa mesma brecha com fragmentos Exandes de gma1s. Os fragmentos escuros são concentraçõos matiores de hematita ou fragmentos de arenito fino com mator quantidade do cimento hematitico. Alếm dêsses fragmentos majores, axistern tambem alguns de aglomerados de calcita, ou quartzo, ou . ainda,feldspatos mf.crogranulares, de extinção ondulante - Os 
grãos de quartzo acham-se frequentemente atacados, apresentando cavidades de corrosão, ocupadas pela calcita. A brecha ( composta aproximadamente por $60 \%$ de fragmentos $40 \%$ de ma triz. Os fragmentos estão desorientados; entretanto, nota-se acamamento dessa brecha na Serra do Paiol.

2- Brecha de côr verde-azulada clara, encontrada nas proximidades do letto do Rio das Antas entre a Barragem e Po ços de Caldas e tambom, isoladamente, na Vila de Cascata . Quando semi-decomposta, essa brecha apresenta côr azul clara ou côr castanha clara, confundindo-se com a primeira jâ descrita.

a- Matriz: 0 exame macroscbpico da rocha fresca yostra matriz afanftica manchada de azul e verde de modo irregu 1ar. As manchas apresentam limite indefinido. Distinguem-so ne matrı fragmentos - grãos de quartzo. Aquêles ocorrem em pequena quant1dade representando, aproximadamente, $10 \%$ da composiçäo total. Ao microscópio, pode-se notar como componente do feltro o plroxênio alcalino, en prismas curtos ou em finas agulhas radiais, sempre ideomorfos 1 , alnda, calc1ta. Esta ultima, forma massa fina de microcristais ou agrega dos maiores sem limites nftidos com os demais componentes da matriz, como acontece na brecha 1, ja descrita. Na brecha en contrada na Vila de Cascata, alem dêsses componentes norvaís a egirina parece estar alterada em mineral fibroso de côr azulada clara. Em alguns pontos da rocha, falta a girina totalmente, flcando a matriz representada s6 por calc1ta. Leucoxênio aparece intersticial.

b- Fragmentos: Macroscôpicamente, distinguem-se fragmen tos de rocha de minerais. Pode-se reconhecer nessa brecha, mesmo macroscopicamente, os fragmentos de rocha insaturada 
ou saturada, dos fragmentos de rocha acida. Fol possivel, por exdmp10, reconhecer fragnentos de gnals alem de fragmentos de lava, arenito siend to. Entretanto, so ao microscbio fol possivel diagnosticar melhor os diversos tipos. Pode-ge dizer

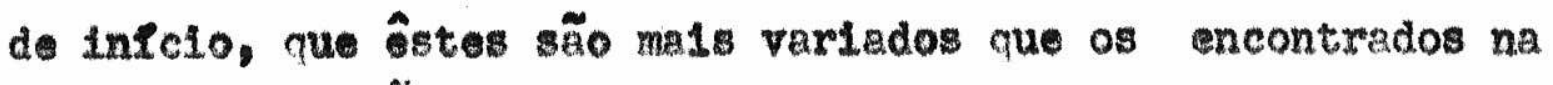
brecha 1. Entretanto, como naquela, mustos são os pedeços de rocha de textura alabksica com plagloclasios riplformes de 21 bita contando magnetita Intersticial. Existem tambiom fragmentos de fonolito ou tingualto cujos componentes são: f́ldspato, -girina nefelina, microgxanulares. Entre os tipos alcalinos grosseiros, ocorre sienito intemperizado com criateis de orto cl.sio, de mals ou menos 2 milimetros de tamanho contendo alguns meflcos representados pelo plxoxênı os dıco mel.s asnda plagloclefso que o torna diferente dos foleitos normels da re

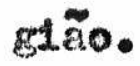

0 arenito o gnals naö foram estudados to microscopjo. AI6m Eêsses fragmentos, ocorrem conjuntos de agregados de fel dspato ou quartzo, que rossal.tam na matriz pelo seu tamanho. Os minerals detriticos mels comuns nessa brecha são estes dols altımos, em proporçōes varıávels quanto aos nfveis de uma sondagem, felta no sit1o Bortolan,pr6ximo A Barragem, junto estrada de rodagem Poços de Caldas a Aguas da Prata. Amostras coletadas a 53 metros 71 metros de profundidade continham, unicamente, feldspato detritico. Na superficie, algumas amostras contêm muito quartzo detrıt1co e raxos gxãos de feldspato. Este vitimo 6 geralmente do tipo plagloclasio o am quanti dade menor ortoclasio - microclinio. Tanto o feldspato como o quartzo acham-se muitas vêzes corroldos o substituidos pola calctta. Alem dêsses minera1s aparece a blot1ta en certos casos apatita. A biotita pode ocorrer em grendes eristais, aI guns de 0,5 cencimetro de comprimento. A apatita $\&$ comum am 
cxistais 1deomorfos. De todos os fragmentos observados, o ma or não ultrapassou o tamanho de 10 centfmetros, sempre encontrados dispostos desorientadamente. Em Cascata nas proximidades da ponte sôbre o Rio das Antas, a brecha estå acamada .

3- Brecha associada diretamente as rochas 1 gneas alcalinas, encontrada ao norte de Poços de Caldas, na estrada que liga esta cidade A Pedra Balão e na Serra do Palol nas elevações que $11 \mathrm{~m}$ tam o planalto a SW. Estas brechas são representadas, na f1gura 1, por triêngulos. Quem sal de Poços de Caldas em visita a Pedra Balão encontra na subida da Serra, que separa êsses do1s pontos, um tinguaito comum de côr negra textura afanftica, que pessa gradualnente a uma rocha de mesmo aspecto, contendo fragmentos de varios tipos. A SW do planalto, capeando as eleveções maiores as collnas que o limitam, encontrado um tinguaito que, quando fresco, de côr negra como o antertor, passando, âs vêzes, a um tipo de granu lação mals grosseira, assemelhando-se" macroscôpicamente a um microfolaito. Apresenta, m pontos dispersos de sua mass. fragmentos de rocha de textura mais fina. Os fragmentos podem estar, da vêzes, distanclados de metros, outras vêzes distantes de alguns milemetros, formando um agrupamento denso.

a- Matriz: A matriz, do ponto do vista macroscepico, \& a mesma om ambos os casos. Diverge esta última daquela quanto $A$ textura, mals grosseira. Ambas possuem grande semelhança na composição. Ao mleroscoppio, a matxiz tem aspecto de tinguat to. A primeira, de Poços de Caldas, porén mais rica em nefeli na, que se epresenta Ldeomorfa em cistals grandes, ate dois miIImetros de comprimento.0s feldspatos presentes são sanidina - ortociesio de 1.5 milimetros, no miximo.Na brecha de Poços de Caldas, o feldspato - nefelina estaó frecuentemente alte rados. O feltro da matriz 6 , em ambas, constituido de cristais 
menores, cujo tamanho \& de 0,15 milimetros, no maxino. 2 composta dos seguintes minerais: piroxênio sódico, nofelina o feldepato.

b.- Fragmentos: Distinguem-se quatro tipos de rrtugnentos, meroscoptcamente, na brecha de Poços de caldes. SR̃o êles os seguintes: rocha esvercleada mut to escura, cujos mineraj.s pris maticos fanerfticos sể, no méxino de un centfmetro; rocha clara de cristals foldspaticos fanerfticos com alguns sônìcos acessbrios; rocha fina afanftica de côr preta; aronito. A pra metra, ao microscópio, mostrou sør uma rocha pixoxênica, zes polquilftica, englobando blotitalque tamber of multo froquen te na rocha) feldspato apatita.Os acessorrios são: titanita, apatita magnetita. Augita ocorre, passando, nas beiradas, a piroxênio sódico. Ao microsḉplo, a segunda se mostra bastante decomposta; do t1po foialto com grandes cristais do orto clásio nefelina. o piroxênio 36 dico e prismético e interats cial. Aparece blotita no contacto do fragmento matriz. Apatita 8 acessbrio comun dessas rochas, na forma de agrthas. 0 terceiro tipo de sragmentos mostrou ser, ao at croscbio, uma rocha microcristalina formada essencialmente de feldspato, ne felina piroxênio sodico. No centro, passa a tex uma textura esferulftica. O arentto fol obseryado nacroscopicameate. Alem dêsses doLs tipos, aparece na Fonte pajol, a três quizenetros de Aguas da Prata, na estrada de rodagem para Cáscata, a 900 metros de altitude, ura brecha de lava da côr paxda esvordeada ou roxa escura, fragmentiria, Iftica, bastante decomposta. A matriz 8 pulverulenta, rica exa hematita, magnetfita (?), cal cita, apatita, clorita a, as vêzes, biotita, onde se dastacam fragnentos de lava basica alcalina, com cristels de cugita o analejta, porfirlcos, de 1,5 centeratron de tamanho meximo. Ou tros fragmentos säo de roche formeda exclustromente de piroxê 
nio, magnetita ou ilmenita, de textura panideomoxfe ou panipi dionorfe, cujo» intersticios são preenchldos por calcita.Como acess6rio, ocorre a titantta, perovsquita (?) e granada (?). Os fragmentos menores são de aglomerados de feldspato om docomposição, possivelmento analcita, clorita, olivina (?) reconhecivel 66 pela forma apatita. Em sondagem de 100 metros de profundidade, essa rocha a apresentou continua, contendo blocos com tamanho miximo de algumas dezenas do contimetros. dispostos desoxientadamente. A sondagem nẽo atingiu o fim da ocorrêncla em profundidado.

4- Brecha piroclástica ou tufo, encontrada na estrada de ferro 11 gando Aguas da Prata Cascata, a 500 motros, apro ximadamente, acima do crumamento daquela, con a estreda de rodagem pare a "Fonte Platina". E rocha fina, afanftica, estratificada, de côx parda, contendo em certos nfvels bombas - blocos acamados. Ao microscoplo, mostra matrir de poeire vulcênica cagtanha escura a pardacenta, decomposta, contendo fragmentos maiores de vidro e lava microcristalina, garalmente angulosos, de côr parda clara, outras vâzes arredondados. Estes são, sిs vêze"s, do material criptocristalino. Haterial se melhante a êste" (e que parece ser tambem tufáceo) ocorre no centro sul do planalto, nos dois afloramentos centrais, marca dos na flgura 1 e tamberm no mapa anexo, na estrada de rodagem que Ilga Poģos de Caldas a Andradas, junto A fazenda Carlito Junquelra. A melhor exposiçẽo $\&$ de 50 metros de comprimento. aproximadamente. I rocha acamada en leitos ritmicos, cuja espessura de 1 a 2 centlmetros no meximo, muito decomposta de côr roxa clnza, contendo quartzo rolado. Acha-se atraveg sada por um dique um sill de rocha, provavelmente alcalina tambefm decomposta. Os leitos se apresentam ligeiramente dobra dos. 


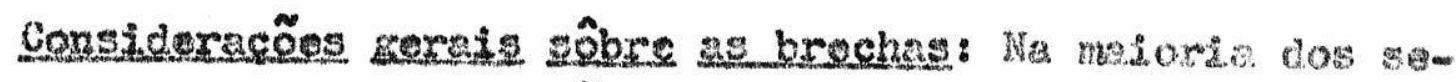

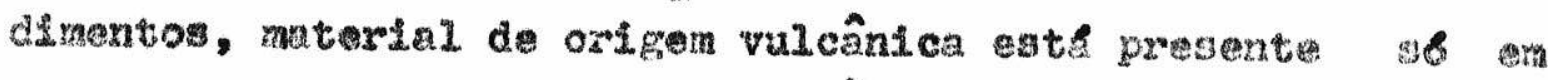
traços, sem importâncie para constituição da rocha. I provă val ou cinzss poeira vulcênica estejam sempre presentes an Sedimentos subaquosos ou sub aereos, formados na suparfeic de terze, pols êste material. Lançado no ar a grandas altitudes, durent explosõ violentas, adquir larga distribulg̨ão. Entretanto, por ser material muito fino originário do magna

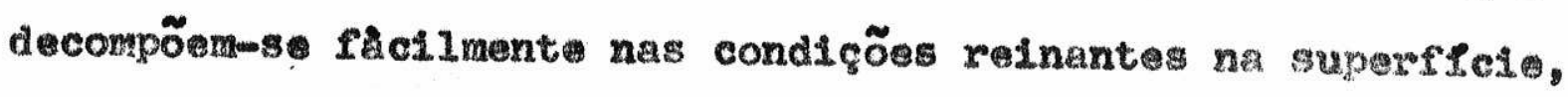
tornando-ge diffell de reconhecer sedimentos arenosos ou argl losos ent1.gos. Em regiones de ativo vulcenf.smo, os sedimen

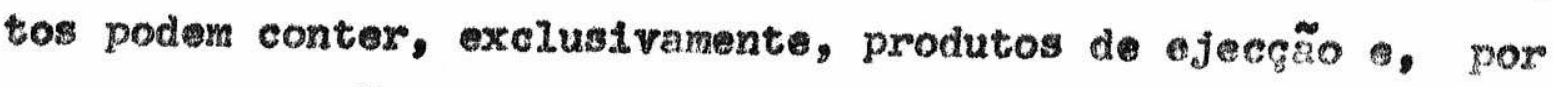
conseguinte, são chamedos de depbs1tos piroclánt1cos. rial formado princlpalmente por axplosóes violentas, ar qu lava - rocha sblida são pulverizadas lançadas do ar. Calndo na superflele da terra, comporta-so como qualquer outro tipo de sedimento, podendo ser retransportado tanto por vanto como por agua misturedo a fragmentos detrfticos de outras procedênclas. Tratando-se de material completament desagregedo

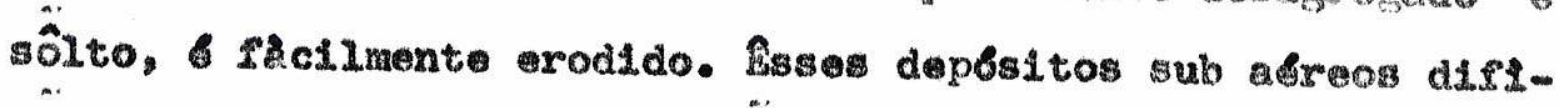
cllmente são preservados da destrulção por erosão. Pox outro Lado, a decomposição química nesses depósitos so reakna com sacllidade, pela clrcunstâncla do ostado subdividido axyermjo frouxo de seus componentes. Tipos mais grosselros aglomere ticos provêm de grandes blocos quebrados arremssados duran to as explosões, frequentenent arrancados do ediflelo vulcênice, tanto na superffele como am profundidads. Tals blocos podm ser arredondados ou angulosos, conforme o tipo de ori gem sedimentação, correspondentemente ambiente acuoso ou sub ałroo. Alên dêsses tipos do brechas vulcânices, hê

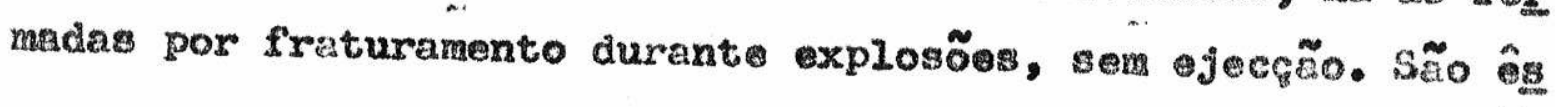


tes formados por afrouxamento - freturamento do "tetop a de "rolha" vulcânicos por fôrças da pressão dos gases acurrulados que procuram saida, Coos (13). Ha nesses casos, un a Justanento de pressões, pelo escape de gases atrevess do con junto de fendes do ediffclo vulcânico. 0 material origininal, fraturado pelas pressōes, pode ser de diversos tipos, tanto da rocha Lgnea consolidada como tembén de matéria piroclást1ca depositada en erupçōes prévias.

Esses três tipos de brecha parecem estar rapresentados na região de Poços de Caldas. A brecha, provâvelmente piroclástica de modo exclusivo, aquela tipo 4 , em che parece nẽo ter havido contaranação por outro material que não o vuLcânico. Nela nẽo fol encontrado nenhum grão de areda axredondado. Os tipos 1 2 so oncuadrarian, talvex, entre as brechas fraturadas por explosต̃o, permendas por gases. A Pavor dessa hipótese estão os fatos:

1- De que essas rochas se encontram ecamadis ear certas exposiço๊es, Indicando sua origem sedimentar primária.

2- De essas rochas conterem quartzo on feldspato arre-

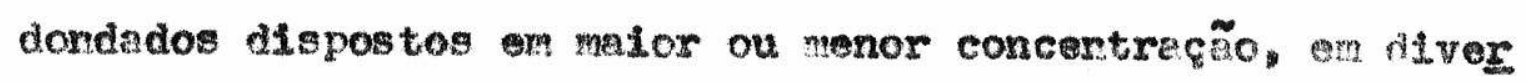
sos niveis, indicando ma1s une vêz origem detrftice de al guns de seus constituintes seu arranjo original sedi mentar.

3- Da terem sofrido modificaçōes na composiçẽo da ro cha, posteriomente a secimenteção. Podems citar a trens formaç̃o sofrida pelos plagioclastos, que, provindo de una rocha possivelmente do tipo do diabásio, forar alterados em albita, perdendo seu conterdo em cllcio. Talvez o preprio Ieucoxênio originário da decomposição da ilmenita, Wilner (27,p.308) - disposto como cimento em tôrno dos irragmentos de brecha, cono tambem nos interstfctos" dos ripas de feldspato do diabésio alterado, são fndfclos des transformeçōes 
sofridas por esas rochas, cuja causa talvez esteja nas intrusões alcalinas.

4- 0 caráter híbrido das brechas, que, como vimos na descrição, apresentam ao lado dos grãos de quartzo e feldspato detriticos também egirina Ideomorfa, às vêzes formando amidalas. Improvável que êste mineral seja detritico, o mosmo podendo-se dizer da apatita, que ocorre como aquêle, âs vêres, em finas agulhas ideomorfas.

0 terceiro tipo de brecha no planalto de Poços de Caldes, que não possui as qualidades dos sedImentos prôpriamen te ditos, 6 a rocha fragmentária de matria tingualtica, tipo 3 ja descrita, que se classifica entre as brechas magmátices. Como foi visto antes, ha dois tipos dessas brechas, um de xenfiltos diversos outro de fragmentos da mesma com posição que a matriz de textura mais fina. 0 primeiro dêles estaria localizado numa fenda, por onde caminharia o magma, atravessando niveis litolbgicos diferentes, de onde teria arrancado fragmentos, trazendo-os a superffele, onde aflora. o segundo, por outro lado, te pequena spessura. Algumas dezenas de metros no míximo, em que os fragmentos se distri buem, princlpalmente na horizontal, am área de $5 \mathrm{~km}^{2}$, aproximadamente, - são sempre de composiçr̃o parecida ou igual a da matrix. Entretanto, êsses apresentam uma textura mais $1 \underline{1}$ na de modo que, mesmo na rocha decomposta, distinguen-se os blocos quebrados do feltro. Parece que foram formados êstes Ultimos por uma quebra de roche Ignea resfrlada, posteriormente retomada englobada por novo afluxo de magma. Há casos one esta brecha forma superficies ou tabuleiros, dis tinguevei's na topografla, com facilidade. A brecha de Pọ̧os de Caldas, cujos xenólitos são de tipos diferentes, mostra pelo menos um caso de provável alcalinização am que, cxis - 
tuls de augtta de fragnento pixoxênico, apresonta mudancas me borda para piroxênio sódico, haviendo una passagem congruento de un a outro mineral, son qua entre ambos haja limites dofd nLdos.

Idade das brechas: 0 estudo das divarsas brechas mostrou que 03 tipos 1, 2 - 3 possuem fragmentos de arenito. Evidentomente, 6 um Indicio de que essas brechas sâo postertores a fomaçõo do gedimento arenoso. Entretanto, na struda de rodagen entre Cascata - Aguas da Prata, na altura dz Foxte Do-

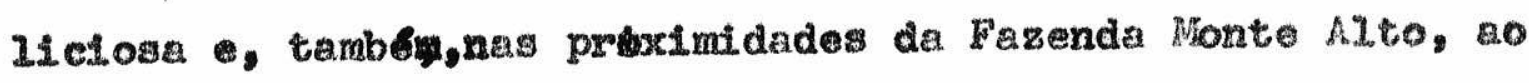
norte de Rguas da Prata, existe de mistura con os detrytos a renosos mita argila fina de cồ cinza azulada salpicada de pontos claros - IInamante ostratif1cada. Soria asso material rosultado da deposiçẽo conjunta de arenito tufo? 0 axamo felto con auxil10 da lupa revela semelhança dasta rocha com aquela piroclastica descrita como tipo 4 das brechas. Intretanto, est\& mais intemperizeda que o tufo proprilamente dito - contem grande quantidade de quartzo detxptico, inexistente na outra rocha. provarel, portanto, que terha havido depo-

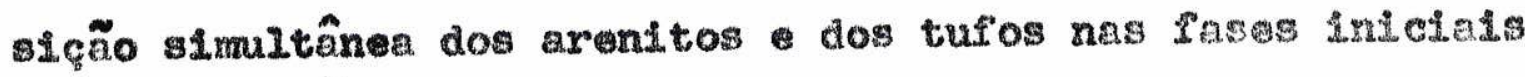
do vulcanlsmo, ou que ambos tenham sido retrabalhados en spo ca posterlor. Devido no astado de decomposiç̃o da rocha arenosa, contendo possivelmont tufo, fol Imposs.tvel detsiminar os seus componentes finos. Dêsse modo, Plca o problems sm

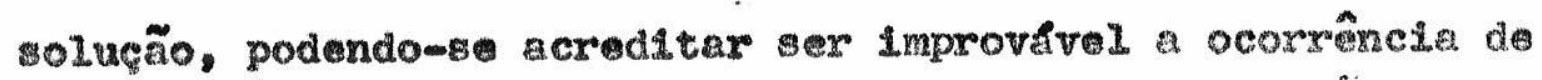
numerosas boas exposiçōes de tufo, pelo fato de êsse ratrral rasistix pouco ao intemperimo arosão, como je vimos. Talvez se posøa explicar a prosence do axenito siltito, tanto no planalto como na sua visinhança, Imaginando to-

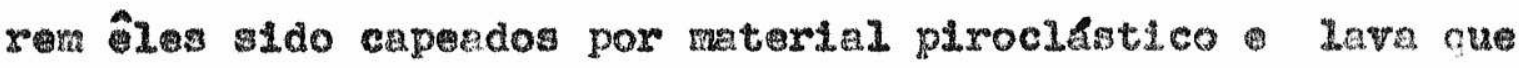

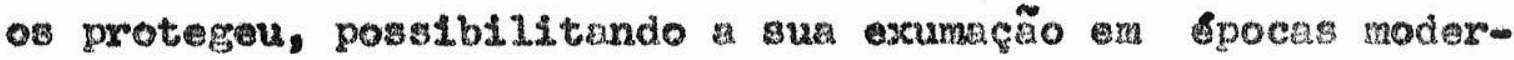


nas. Og arenitos mais afastados da região vulcênica não t riam tido a mesma sorte, sofrendo destruição erosive jf ta pocas remotas. De qualquer forma, as brechas parecem ser pos teriores ao arenito anteriores ao final. das ultimas manifestaçōes vulcênicas, pols estẽo cortadas por intrusões alca linas (tinguato) en muttos pontos onde afloram. Alem disso, possuem, om quantidade, fragmentos de diablsio, Intrusivo sob a forma de diques ou sills nos arenitos do Rguas da Prata. Bsse detalhe revela seren estas brechas tarbin postertores As eruptivas bisılcas, fato êsse ju citado por Freitas $(29, p, 8)$.

Martin Korm $(26, p .121)$, estudiosos de vulcanismos alce Linos na parte ocidental da Rfrica do Sul, estabelecen as se guintes relações entre aquelas ocorrênclas as nosses , com base na reconstrução das "Terras Condwânicas" feita por Du Toit:

2- He grandes semelhanças entre os secimentos trifissi cos da Rfrlea os sedimentos do Brasil meridional, jigados no vulcantsmo alealino.

2- He mitas semelhanças de rochas extrusivas nas duas Areas, to ponto de vista petrografico.

3- Ha uma continuação linear na disposição das ocorrêncins alcelinas nos dois continentes.

4- As melores ocorrênclis alcalinas nos dols continentes maxcam o fin das erupções bésicas.

Acreditemos, com aquêles autores, que, em Poços de CaLdas, as mentfestações alcalinas vieram, provâvelmente, encex ror no tempo o ciclo de cruptivas básicas, como demonstram os fatos acima. 
AS ROCHAS CLASTICAS NO ESPACO.

- A rigura 8 mostra três perfis, que cortam o planalto de Poços de Caldas na direção este-oest. A distância entre êles \& de 3,5 quil6metros, aproximadamente, começando de Rgras da Prata para o norte. Os perfis nostram as divarsas posiços que os afloramentos de aronito tonnm nessa regĩo. Eviciente-

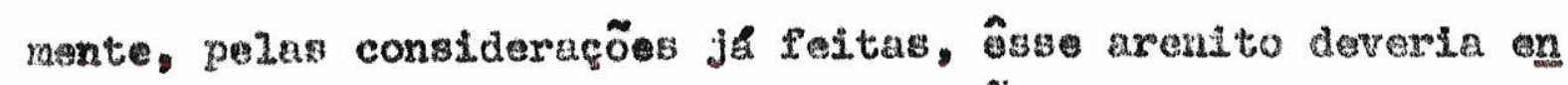
contrar-se om nivela equivalentes aos das demejs rochas sedimentares de bacia do Parana. Fntretanto, ocupa ne serra do $\mathrm{M}$ xunte, o nfvel de 1580 metros de altitude, aproximadenerte. 0 mesmo fanôneno ocorre dentro do planalto, en que os arenitos

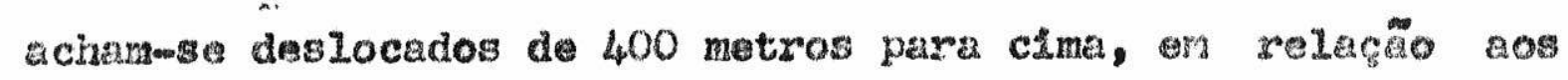
de Rguas da Prata (a 820 metros de altitude). Alea disso, cowo ja vimos na plgura 1, o centro do planalto esta livro do

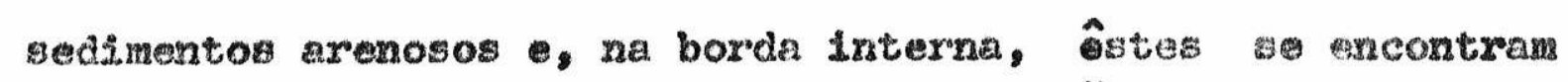
juntos o sôbre o tinguzito poiaito, nas mesmas cotas titime txicas (ao rerior de 1300 metros de altitude). Houve, portento con tôde a probabil1dade, levantamento dos aronitos.joder-se1. penser que êstos tivessem ocupado as ramas das elevações do sope ao cume dendo a false impressão de levantumento. Entretanto, existe uma separação montanhosa entre os axendtos de dentro e de fura do planolto. Alem disso, esses rochas do incerior do planalto em geral mergulham para dentro do mesmo, mostrondo meis una vez terem se dissociado estruturezmente. con relaça aos do forta.

Os arenitos do planalto parecem estax apoicdos dirotames te sobre rocka alcalina.Essa afirmaça se bused ta un aro ramento que ocorre nos arredores da cldede de pogos de Caldas, a Ww da nesma, na Serra de Pogos. Nesse local, o axerito acha - se apolado sôbfe o tingualto, mexgulhendo para o sul, aprosi 
madamento de 30 an arloramento, que sobe quase ate o cure dessas levaçōes. Lambramos tamberm que o tufo ja descrito, decomposto, que ocorre no centro sul do planalto, ocupa as mesmas cotas que o arenj.to da borda, 1sto 6, aproximademen to 1300 metros de altitude. Como rexemos adiante, êsse um dado mito importante para esclarecer as disposiçôe estruturais da região. Como ja vimos, a brecha acompanha interna mente a bolrada montanhosa alcalina. I Interessante notar a semelhança entre as brechas I 2.Apesax de exibirem nos afloramentos com diferentes côres, 1sso provâvelmexte se de ve circunstâncias secundáxias de decomposição intompe rismo. Fato Interessante, que demonstra a sua semelhença, \& - de conterem, como fragmentos, grande quantidade de diabhsio :, multas vêzes, axenito detritico. Parece que Lormam uma falxa continua desde Pogos de Caldes ate Rguas da Preta -n Iinha semi-circular, provivelmente ocorrendo em maior eg cala do que verificada no campo; posis, como vinos no plenaito, o intemperismo multo intenso, tornando diffeil a $I$ dentificação perfelta dessas rochas nas collnas a demals pon tos, onde são encontradas. Acreditamos que essas brechas te whan tido sua composição deterninada pala litologia subjacente. Assim, em Rguas da Prata, onde ocorre mito arenito - díabisio,a brecha r riea dêsse material dos produtos d decomposição alteração do díabísio, como vimos. WaLs pare perto de Poços de Caldas, onde provâvelnente a Influência al calina se torna major, o feltro dessa rocha so transforma, passando a conter enorme quantidade de piroxênio s6́dico. In Fellzmente são poucos os dados que possulmos sôbre a sspessuxa vertical dêsse tipo de rocha. Adianto voltaremos a as sunto. 
INTERPRETACOTS: Ate agora foram descritos e interpretados fe nômenos observados. Para chegarmos a uma interpretação plausivel geral, muitas inferências terão que ser feitas sem ter mos para la confirmação. Essas versões serão, portanto, do tipo conjectural. No ontanto, serk feita uma tentativa para deduzlr dos fenômenos observados em superffcie aquêles que o correram nas profundezas inacesslveis, ou,ainda aquêểes cuja verfficação direta impossfvel.Observando o mapa gèolbgico, - que primeiro chama a atenç̃o a disposição dos arenitos brechas. 0 restante do planalto, a grande area central, apre senta aspacto homogêneo pouca variabilidade litologica. Qual seria a razão para as rochas clásticas ocuparem a os trelta faixa ao longo da cadela montanhosa, que limita o pla nalto?

Orieem das brechas: A origem sedimentar das brochas 1 e 2 pode ser verificada om alguns afloramentos pelo acamamento, apesar delas nem sempre apresentarem quartzo ou feldspato de trfticos. Tal se da em cascata, onde a quantidade de quartzo - geralmente pequena - tambén perto da ponte sôbro o Rlo das Antas, nas proximidades de Poços de Caldas.

Como vimos, existe grande semelhança litologica en tôda a extensa faixa om que ocorre esta rocha, de meneira que 6 plausfvel considerar a malor ou menor concentraçẽo de grãos arredondados de quartzo ou feldspato, como uma variação simplesmente faciologica.

Caracteres sedimentares das brechas:

1- Acamamento certos pontos, como visto acima.

2- A presenço. frequente de grẽos detriticos de quartzo - feldspato na sua compostęão, que devem provir dos sedimentos arenosos da superfície. 
Caracteres vulcânicos magmáticos das brechas:

1- Blocos de arentto siliclefcado recristalizedo blocos de gna1s, que tomam parte como fragmentos majores da brecha, possivelmente arrancados de pontos profundos, trezidos a superfici - atirados junto com os demas eject81itos.

2- Os cristals Ideomoxfos de piroxênio sódico con tesstụ res lgneas anigdaloides os cxlstais Ldëomorfos de apatita.

3- Movimentação - fraturamento,talvez causado pox explo sões acoraodações vilcênicas indicadas por:

- Calcita, apresentando planos de geninação oncurvados.

b- EsctInção ondulante do quartzo.

c- Textura "mortelro" da brecha, alguns pontos. Bxplicação: Com tôda probabllidade, essas rochas devora ter sofrido a percolaçã̃o de gases, pols êstes poden encontrax caminho aberto no tufo, arenito material pirociastico poroso, afrouxado cm consequêncla dos abalos vulcânicos. Os geses alcençando a superflele, sofrem frequentement reaço de oxidação com o ar atmosferico Barth, $(6, p .153)$, havando, om conse quênc1a, Grande aumento de tenperatura. Talvez asta Iltima se Ja surflelente para promover a fusẽo do quartzo dos arenitos que. À vêzes, aparece velos ou na forma de quartzito, pro duto de recristalização. I faro conhecido, quo a cgua, nas v zinhenças da sua temperatura critica $\left(375^{\circ} \mathrm{C}\right)$, Ilgeiramento Eelda capaz de dissolver vidro, sillelo outros silleatos. Acima dessa temperatura, a Agua se encontra no estado de vapor, qualquer que saja sua pressão.

Howen $(8, p .84)$ aftrma que, durante o processo de oristaIização do magra alcalino, he um enriquecimento de volfteis. taia como: $\mathrm{H}_{2} \mathrm{O}, \mathrm{CO}_{2}, \mathrm{~S}, \mathrm{Cl}$ etc.. Tal o aumento de voletois no magma alcalıno, qu 
ner Verhoogen $(33, p .308)$ entre os pegmatitos. Desse mane1. ra serla fecll para âsses compostos, quer na forma de geses, quer na forma de soluçōes, atacar - corroer os grãos de quarszo de certas rochas e, ao mesmo tempo, enriquecê-las de ou tros minerais. Explicar-je-ia, assin, o pequeno grau de arredondamento nos grãos de quartzo dos erenitos, principalmente os do planalto, diretamente onvolvidos nos fenômenos vulcânicos. Por outro lado, certos minerals, tals como a zirconita, nada sofreram, provâvelmente devido a grande estabilidade dê te minexal.

possivel que as consideracôes feitas acima possam ex plicas os processos metassométicos que permitiram a formeço de alguns minerais eplgeneticos nas brechas e nos axenitos, tals como: 1eucoxênio, anatásto ldeomorfo, albita nos plagioclasios componentes dos fragmentos do disbasio ytc..

De qualquer forma, existe no longo dos afloramentos de brecha uma zona de fxaqueza ovidenclada pelos seguintes fatos:

En primelro lugax, porque nêsse local ou nas suas vizd nhanças foram necessários vuIcōes que produzissem o matexì płroclást1co vulcões s existem nos pontos am que haja posalbilldades do magma vir a superficle. No entanto, fazendo uma regsalva, as brechas piroclestlcas podem formar-se afastadas dos rulcōes de uma certa distância, pelo fato dos blocos serem expelidos, nem sempre calndo nas proximidades de onde foram Iançados.

Em segundo lugar, como se pode ver no mapa geologico ane xo, existem lavas, ocorrendo proximas aos afloramentos de bre cha. Geralmente, as corridas dessa massa fluida não se afas tam muito do cone vulcânico, irxadiando-se alguns quilonotros apenas da sua origem.

En tercelro lugar, a homogeneldade da litologia cuntral. 
do planalto, vide mapa geologico anexo.

Em quarto lugar a ocorrêncla de fontes quentes moç pos de Caldas outros tipos em Pocinhos do Rlo Verde, Rguas da Frata o suas vizinhanças, nas regtôes que circundam o plana to.

Em quinto lugar, a ocorrência de caj.cita en gronde quan tIdade na brecha, mineral Inexistente nas rochas virinhas 2.1 calinas a proveniente de profundidade, no caso, whand $(31, p$. $250)$.

Com êsses dados apontados actma, suxgen dificuldades de ordem estrutural. Por exeinplo, pode surgix a seguinte pergun ta: ate que profundidade se encontrarta faixa brechosa? if vimos are, por sondagem, se apresenta continua, ate aproxime damente 200 metros de profundidade. Existem algunas boas es posiçōes, ao Iongo do vale do Quartel, ewtre Cascata e Rguas da Prata, em que se ve contato vertical entre brecha e roche Ignea alcaline. fisses afloramentos, Litológicamente semelhan tos, seguem com pequenas interrupçōes da cota, de 1200 metros de altitude a 820 metros de altitude. Deve-se então pen sar em uma faixa de brecha de 400 metros de profundidade ou deve-se pensar om uma camada que se depositou en pearena espessura, descendo o planalto ats a soleira das montanha, ex um vale preformado? Por enquanto, imposstvel dax una resposta a êsse problema.

Como vimos antes, \& fato bem conhecido que os vulcões condf clonam a subida do magma ate a superfici, aparecendo nos pontos fracos da crosta. De fato, so onde existem fendas que permitam a passagem de materla lgnea para o exterior que so formam os ediffcios vulcânicos. Assim, atહ mesmo nas zonas estéveis da crosta, os vulcões seguem alinhamentos estruturais, Hans cloos $(14)$, Umbgrove $(35, p .296-297)$ obed - 
cendo a condições tectônicas de falhas e fissuras. L interes sante notar que essas rochas vulcênicas de continentes sẽo, m geral, do tipo basbltico seus diferenciados. Rochas leu cfticas podem aparecer nesses casos; entretanto sou carkter alcalino parece ser causado por circunstânelas locals, S1tter $\left(32, p_{0} 373-374\right)$. Os vulcões devem ter surgido ao redor do planalto, onde existem varias evidências de infiluência magmát1ca, direta ou indireta. al que o próprio magma pode vir a superffe1e, como mostra a brecha da Serra de Poços, no ceminho da Pedra Balão, como vimos. Cloos (13) veriflcou, am vấios vulcões da Suabia, que o proprio"neck"consolldado dos vulcōes pode tomar o aspecto de brecha, quando quebrado afrouxado durante o escape da pressão interna. Verificou êle a existêncla de dois tipos extremos de brecha, a dos blocos arredondados, com movimentaçẽo, expulsẽo de material e injeção de gases concomita ntemente, segundo grupo mals simples, de fragmentos angulosos. Neste litimo caso, os blocos seriam fraturados devido a explosão, ou simplesmente exprisos por fenda, sem atrito suficiente para perderem os ângulos.0s nos sos dados permitiram enquadrar os blocos tanto ex um tipo co mo om outro; por 6 , tal a complexidad dessas rochas tal 6 a falta de boas exposif̧os que acreditamos ser diffcil, tal vez impossfvel, situar na região estudada, os vulcôos do pas sado.

As arandes estmuturas: A altitude dos arenitos am Rguas da Prata - adjacênclas, em relação aos do planalto, figura 8; o mergulho acentuado, muitas vêzes vertical, das texturas flụ́ dals nas rochas alcalinas da boirada; a marcante saliêncla desta ultima; o contacto quase vertical do gnals e rocha alca lina,parecem indicar ter havido avanço da intrusão para o al to, durante o seu "mise en place".Tanto os picos marginals do 
planalto, corno o deslocamento dos arenitos com relação ao extexlor do planalto, mostram haver ume declividado da ordom de 500 metros en um quilómetro, tomando como relação o sop ax terno. Admitindo que a fntrusão tivesse causado um abaulamento, em tal êngulo, relativo a horizontal, construimos, em escala reduzida, três perfís do planalto, para ge foucrom espoculaçōes sôbre as condiçôes estrutura1s ox que teriam se or1ginado e situedo as brochas, figura 9. Experiências de cloos - Ridel citados por Balk $(2, p .101)$ mostram que massa em movimento 00 longo de obstrusẽo estacionaria, inumeras fendas sur gem no contacto da part morel - estavel. Ess s serio perpendiculares $\mathbf{s}$ Iinhas de máxima distensão local. Essa diração ficilmente determinada, pois o perpendicular is linhas fluidels da Intrusão. Se o matertal usado para a exporiêncta fôr relativamente fluido, as fendas estark̃o ao longo da faixa fina, no ponto onde a borda estacjontria forma uma flexto brusca, figura 10. Entretento, quanto menos fluido fố o materlal, meis suave a flexêo o mals larga sere a zona d froturo, figu ra $10 \mathrm{C} .0$ nesmo acontece $\mathrm{i}$ encalxente solideria a intrusiva, nas proximidadas do contacto entre ambas. Das figuras 9 e 10, podomse chegar seguint conclusão: no alto o nes bordas dessa estmuture que se desenvolvem melhor as fôrças de tensão. Formar-se-iam, assim, nessss locais, fendas poŕ onde entraria - magna con mals factuldade.No segundo exemplo da figura 9, ha abaulamento externo, con translação de blocos falhedos, sem dernamento, enquadrando-se no caso 6 de Balk. O mesmo se de no torcesiro esquena da figura 9, em que fol xepresentado um auposto levantamento o abatimento. Nesse esqueme, entre os blo $\cos A, B$ C seus simbtricos, nêo s6 houve maior movimentaç̃o, como tambem as superfictes de contacto, representadas por 
linhas grossas verticais sâo mis curtas, relativanente 20 s outros blocos do conjunto. Sob o ponto de vista geonetrico,se guindo 08 moldes traçados, as zonas fracas estariam na cherrelra, Isto 6 , na borda da convexidade intrusiva, nes groximidades desta com a encaixante. Na figura 11, mostremos três perfía da borda un teórico hipotético. Como ge vê, a sene"lhança \& aggestiva. Os dados relativos ao levantamento geologico parecem mostrar ter havido um soerguimesto por falhe.Ate que ponto a interpretaçẽ

Abatimento, exosão ou explosão?Várias hipbteses podem ser lançadas pare explicar tal situaçẽo atual das zoohats clisticas no planalto.

1- Bor explosão pode ter havido o arrasamento do centro da massa intrusiva, ficando apnas alguns tastomuh so teto na belreda. Esta primeira hipotese pouco plausivel, porque oxigiria uma fôrça explosiva tremenda para livrar o plensito de toden a sua cobextura, correspondente a mishares de quilione tros chioicos, Shand $(32, \mathrm{p} .248)$. Por outro 1ado, deveria hever nas vizinhanças externas, ao redor da região alcaline, blocos - raterial desagregado ou pulverizado resultante de tas acom tecimentos, o que parece não ser o caso. Fxarninemos entio mals dues hir róteses.

2- Pode ter hevido um abaulamento para o extericr provocado pela intrusão, Pacliltando a répida exosc̃o dos pontos al tos dessa strutura, determinando o desaparecimento dn chula. 3- Pode ter havido um abatimento do tato na partie central do planalto, determinando o englobamento do mesno pelo magme alcalino, sem doixar vestiglos na suporflcie.

A. xoßão, gindo constantemento nas formas gealogicas atuais, fenômeno aue deve tex ocorrido no pessado. Nible impe 
de que logo após a intrusão ter produzido novas formas na superflcie exterior, estas comegagsem a ser modificadas pelo trabalho da erosão. Formar-se-1a, assim, uma estrutura Igual 2. de Poços de Caldas, arrazada no centro, onde aparecem os t1 pos Igneos plutônicos, conservada na periferia, onde ainda aparecem os restos do teto, as rochas clésticas. Entretanto, existe um dado de campo que perturba êste racioclnio; trata se da rocha provàvelmente piroclástica, que ocorre no centro sul do planalto, figura 1. Este tufo, como vimos, esta nas mes mas cotas altimetricas que o arenito da beirada ( ao redor de 1300 metros de altitude). E possfrel que, depois de erodida a parte central do planalto, tIvesse se depositado êsse material consequente de um vulcanismo ativo multo demorado no tem po geologico. Mals facli 6 , porém, pensar que a causa dessa situação em Igual nivel das rochas clásticas no centro na periferia, esteja IIgada a um abatimento central proposta na hipotese terceira. Analisemo-1a. Para haver um abatimento do teto 6 necessário que êste sofra um solapamento englobamento pelo magma alcalino, em grandes ou pequenos blocos, como o tipo de "subsidence" de Billings $(7, p .286)$. Para que tal se desse, seria necessário que a possfrel capa, gnais arenito, tivessem densidade malor que o magma alcalino, podendo afun dar neste por gravidade. Seguindo una tabela de Daly $(15, \mathrm{p} .47$ 48), não hå prâticamente diferença de densidades entre gnais - rochas alcalinas, sem contar o arenito. Esto Ultimo, pelo fato de ser poroso, provàvelment se comportaria como rocha de densidade menor. Entretanto, o próprio Daly $(15,0.47-48)$ se refere as rochas om alta temperatura como possuindo menor den sidade qua as mesmas no estado solido, alnda frias. Alam disso, essa propriedade de ter diminulda a densidade talvez se 
acentue om magma do tipo alcalino, rico em gases, como \& o ca so. De qualquer forma, o gnais não encontrado no interior do planalto com exceção dps fragmentos constituintes da bre cha o arenito aparece nos raros pontos em que o contacto visfvel, diretamente, sôbre o magma alcalino, como se tivesse flutuado no mesmo. Alem disso, como vimos, a brecha magmetica encontrada no planalto, do lado interno da Serra do Paiol o uma rocha tinguaftica contendo fragmentos à vêzes angulosos de una rocha microcristalina. Este fato, aliado A pequena ospesøura dessa brecha e, ainda, sua distribuif̧̃̃o em Area, suge re ter o magma vindo ate a superffci- Terla ontão se resfria do, quebrado e, posteriormente, sido retomado por outro avanço do magma. Se tal realment aconteceu, o teto paroce tor si do representado pela fina camada de maga solldificada. Onde estaria o teto primitivo de arenito o gnais? Teria tldo no interior da massa Ignea ascendente? I diffcil supor que, no caso de tor havido abatimento, não ter ficado nem um bloco na superfleie, resto do antigo teto, ou que o magma alcalino não tivesse se acidificado com inclusões de grats e a renito.

De qualquer form, o abatimento, caso tonha realizacho não deve ter sido maior que algumas dezenas de metros,pois os sedimentos mergulham pouco para o interior do planalto. Maxtin - Korn $(26, p .91)$ apontam êsse detalhe como indicio de pocuenos abatimentos.: preciso, no entanto, fazor uma ressalva com referência aos arenitos do norte de Andradas. Ness local. om uma faixe de algunes dezenas de metros, o arenito o siltito encontram-so dobrados, cortados por veios de quartzo mer gulhando quase na vertical. Pode-se apelar para a primelra o sogunda hipbteses em conjunto, como solução provisorila park êsses problemas, que cada uma separadamente não consapue re - 
solver. Portanto, para finalizar, podemos dizer que o peoueno nưmero de evidências nos Indicam ter havido um levantamento dos sedimentos, produzido pela rocha alcalina.Êstes devem ter -se mantido sôbre ó magma alcalino, Posteriormente, a arosão - pequeno abatimento devem ter dado ao planalto sua configura ̧̧̃̃o atual, eliminando do centro o teto primitivo.Nesse local, manchas de tufo devem ter-se depositado, apb́s a fase de eroรล๊o.

\section{CONCLUSORES:}

1- Na regtão de Poços de Caldas, ocorrem sedimentos arenosos, siltosos brechas vulcânicas, formando uma faixa,junto ao contacto rocha alcalina - gnais, a 1300 metros de altitude aproximada. A oeste da área alcalina os arenitos apare cem, capeando o gnais om uma elevação de 1580 metros de altitude. Fora dessa area não se encontrou ate agora ocorrêncla dêsse sedimento.

2- A análise mecânica revelou serem os arenitos e siltitos bem selecionados. "Os coeficientes de seleção variam de 1,1 a 3,6. A média dos coeficientes de seleção 1,7. As me dianas representativas do diêmetro em milimetro dos grãos com ponentes do arenito variam de 0,10 a 0,54 . A grande maioria possul d1âmetro de 0,3 mflifmetros.

3- Quanto forma, fol estudado o arredondamento dos com ponentes do arenito siltito. A media do grau de arredonda mento da fração 0,500 milimetros a 0,297 milimetros da fração 0,074 a 0,044 milimetros, deu valores multo próximos en tre si, sempre inferiores a 0,5 e superiores a 0,2 .

4- A análise mineralógica revela uma grande vartabilidade no teor em quartzo, de $90 \% 220 \%$ nas amostras, predominando porcentagens acima de 70. O feldspato varia em teor de 0 a 
10\%. Os minerais argilosos, muscovita, bauerita hidroxidos - bxidos de ferro, em conjunto variam em porcentagen de 1 a 79. Predominam as porcentagens inferiores a 30.

5- Ha grande váriabilidade no teor de minerais pesados nos sedimentos estudados. Nunca ocorrem quantidade superi or a $1 \%$ com relação ao total de componentes. Predomina a gir conita sempre presente todas as amostras. Bm ordem decres cente, aparecem ainda os seguintes minerais: anatkisio, turma lina, rutilo, granada, monarita, hornblenda, apatita e corrin don. A maior quantidade variabilidade de minerals posados ocorre nos sedimentos de Aguas da Prata arenitos da Serra do ilitrante, amostras de 7 a 11 . Alem dêsses minerais, ocorre multo leucoxênio como cimento no arenito.

6- Os grãos de areia, examinados em relação ao brilho, mostram-se geralmente foscos. Pelo fato do material examinado apresentar baixo grau de arredondamento, concluiu-se que os grẽos foscos adquiriram êsse carâter, por corrosão.

7- A máxima espessura alcançada pelos sedimentos de a proximadament 90 metros, Aguas da Prata . Trinta metros de axenito no tôpo a 60 metros, aproximadamente, de siltito com intercalaçōes arenosas, abaixo.0 material fino apresenta acamamento laminar paralelo e rftmico; quando inclinado, os ângulos são menores que $20 \%$. 0 arenito apresenta estratifica ção plana, paralela, ou cruzada ângulos ao redor de $30^{\circ}$. En certos locais, o arenito toma un fácies arcosiano, com estru tura de depsisito torrencial; outros pontos, apresenta nivels de seixos. No planalto, falta en geral o siltito as camadas de arenito parecem ser pouco espessas. Acham-se cortadas por intrusões alcalinas e, certos pontos, por intrusões båsicas (diabásio). As intercalações de arenito o siltti 
to parecem Indicar um ambiente misto de sedimentação aquoso - élico com predominância final dêste ulitimo.

8- Pelo fato de não terem sidö encontrados fóssels nes ses sedimentos, foi impossfrel data-10. Estabeleceu-se então uma correlação com outros sedimentos em bases litologicas. Fol felta uma comparação com sedimentos flúvio - glacials, arenito Botucatu - Bauru. Os minerais pesados os resultados granulométricos indicaram algumas semelhangas on tre o arenito de Poços de Caldas - o arentto Botucatu, cuja correlação foi por nós aceita provisôriamente, atribuindo a êle 1dade triassica. A hipótese de se tratar de arenito Bau ru fol eliminada, pelo menos em Rguas da Prata e ao norte de Andradas, pelo fato de o sedimento estar cortado pelo diabás1o nesses locais.

9- Como brechas foram classsificadas as rochas fragmen tárias ligadas diretamente ao vulcanismo alcalino. Ocorrem em afloramentos, acompanhando internamente a borda montanho sa do planalto. São elas de dols tipos principais:

$$
\text { a- Detrit1cas b- Magmaticas. }
$$

- Detrlticas: Essa rocha ocorre de Poços de Caldas ate Aguas da Prata em pequeno afloramento isolado ao norte de Andradas, na fazenda Pinheirinho. Os fragmentos dis põem-se, geralmente, de modo desorientado, em massa fina afanftica castanha ou azulada esverdeada. Os fragmentos mais comuns são de diabásio alterado e, em menor quantidade, sie nito, quartzito, lava e gnais. Entre os fragmentos de minerais predomina o quartzo detritico feldspato, feralmente corroidos - substituidos por calcita. A matriz, isto $b$, feltro da brecha, a rico em calcita, hematita, egirina e,em menor quantidade, em leucoxênio, apatita - biotita. Essas 
rochas aparecem acamadas om Casceta ainda nas proximidades de Poços de Caldas, junto ao Rlo das Antas. Alêm dêsse tipo, existe roche pirociéstica prigriamente dita, mito fina, aca mada, con Iragmentos de vidro masse castanhe escura, decom posta, encontrada na base da Serra do Palol no centro do planalto, em pqueno afloramento.

b- Magmit1ca: A matriz tingualtica $\odot$, portanto, de rocha Lgnea alcalina, contendo fragmentos de rocha pircoxênica, lava, arenito e folalto, nas proximidades de poços" de Caldas. Na Serra do Paiol, nos limites montanhosos a oeste do planalto, essa rocha do mesmo tipo. A matriz apresenta textura mais grosselra os fragmentos são da mesma rocha,po rom mais fina, microcristalina. Esta altima brecha ocorre arn Area de 5 quilometros quadrados aproximadament e om espessu ra no míximo de uma dezena de metros.

10- Quanto a origem:

As brechas do tipo a sẽo dotriticas, primeriamento, posteriormente, modificadas por movimento, percolaçẽo de soIuções gases. Os indf́clos que apolam essa conclusão são os seguintes:

1- Quantidade grande de grãos de areja arredondados na matriz.

2- 0 acammento dessas rochas en algumas exposiçōes.

3- A ocorrêncta de piroxênio sódico ideonorio na mátriz formando em alguns casos amidalas ou agulhas.

4- A albitizaçño dos feldspatos componentes do diabé \$L - a corrosão dos grẽos de areia.

5- Cominação encurvada da calcita texture "mortei. ro" de alguns fragmentos.

As brachas do tipo b são magmaticas, porque a matriz de rocha Ignea (tinguatio ou lava piroxênica). 
11- As brechas são posteriores ao arentto dfabásio, no tempo, pelo fato de conterem fragmentos dessas duas rochas. Devem ser anteriores as ultimas manife tações alcalinas, por estarem cortadas por diques de tinguaito.

12- A posição dos arenitos no planalto, a 1300 metros de altitude m relação aos da faixa exterior a 820 metros, mostra tex havido um levantamento da área de intrusão alcalina.

13- 0 levantamento deve ter sido m bloco causado por falha, sem basculamento, porque:

1- 0 arenitos do interior do exterior do planalto acham-se de modo geral pouco perturbados em ângulo.

2- As expos1ções de arenito no interior do planalto, ao longo do cfrculo alcalino, encontram-se aproximadamente no mesmo nivel (cota de 1300 metros).

3- 0 contacto das rochas alcalinas da encalxante gnaissica \&, praticamento, vertical.

4- A textura fluidal do contacto das rochas alcalinas com o cristalino 6 , quando visfvel, tamberm aproximadamento vertical.

14- He alguns indfcios de que o planalto tenha sofrido pequeno abatimento central. Os indfcios são os seguintes:

1- Os arenitos mergulham para o interior do planalto, de modo geral.

2- Do lado de fora, na Serra do Mirante, o arenito s tâ situado sôbre o gnais, om maior altitude (1580 metros) que os do planalto ( 1300 metros).

3- Ocorre, no centro do planalto, uma rocha possivelmente piroclásitca, em mesmo nfvel que os arenitos da borda Interna do planalto.Este vitimo,que o argumento mals forte, mogtra que houve ou abtimento, ou o vulcanismo da re 
gião demorou-se ativo en trapo suficientement longo, para que a deposição da rocha pirocléstica so doss depois di rosäo alleangado tal nival.

1.5- Com base nos dados geolbgicos, inferências conjecturas; fol tentada uma representação esquemética da sucessão provâr l de acontecimentos geologicos ocorridos na região de Roços d Caldas, rigura $12 ; \mathrm{a}, \mathrm{b}, \mathrm{c}, \mathrm{d}$.

A primeira, a, mostra a fase anterior a intrusão, em que os axentos ocuparam a regĩa. Nos lagos da belxeda desért1ca depositou-se silt arglla.

A segunde 11 gura mostra a intrusão v vulcanismo.

A terceira figura mostra o abatimento hipotetico que fos exageredo no desenho.

Esta talvez seja a fese on que se formaram ws brechas hibridas.

A quarta figura mostra, de modo grosselro, a formin situ al do planalto, apbs longa açẽo erosiva. 


\section{BLIOGLEIA CXYALA}

1.w Hagnold, h. A. - the physles of blown sand and desert du nes, 265p., Methuen ik. Co. Mtd., dordxes. 194.

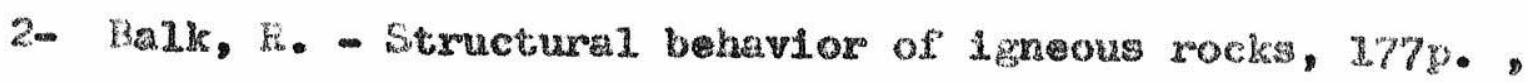

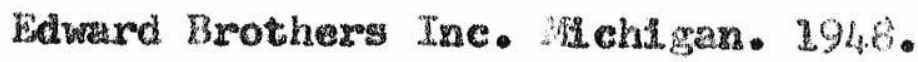

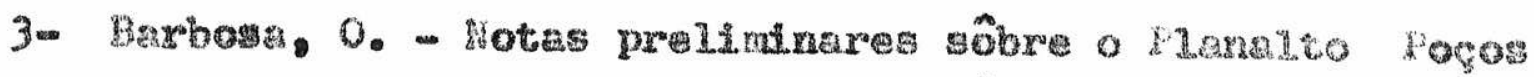
de Caldas suas possibilidaces Rconôn eas, Gex.

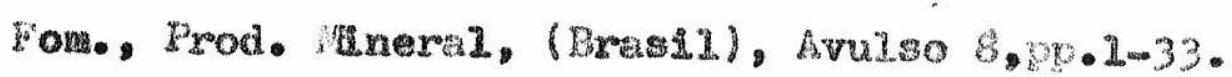
1936.

$4=$

- Sobbre a Iuade des Hoches Alcalines e a Oroiger do Planalto de Pogos de Caldas, drn. Set., vol.

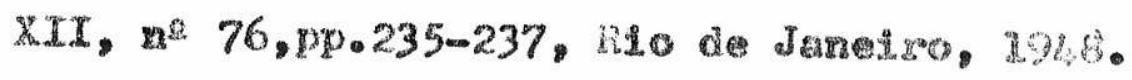

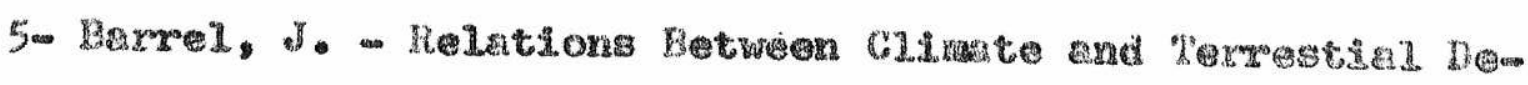
posits, Jour. Sied. Pet, พ.21, n.3, pr. $147=1540$ 1951.

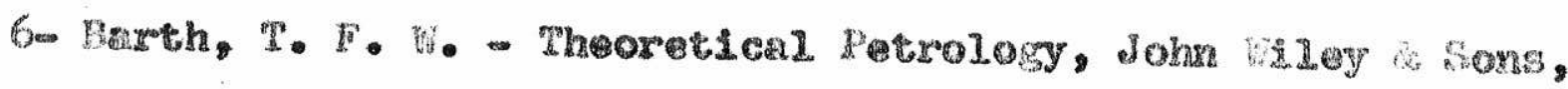
Ine. Hew Xork. 1952.

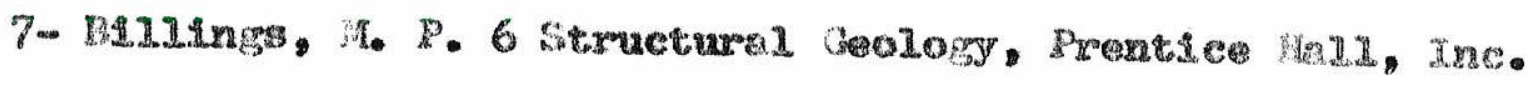
Hew Xoxk, 1942.

S- Bowem, N. T. whe Wvolution of Hhe Igneoms hocks, Dever Nub., Ire. Wew Kork. 1956.

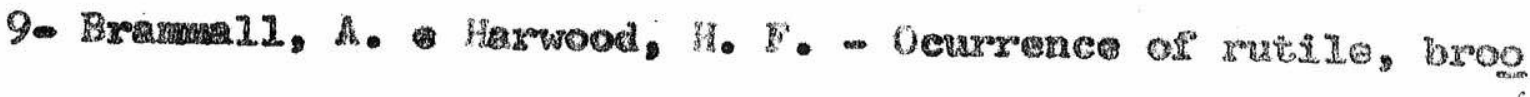

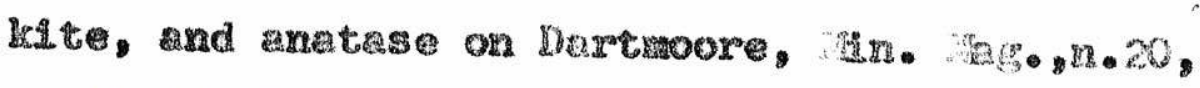
pp. 20-26,2923.

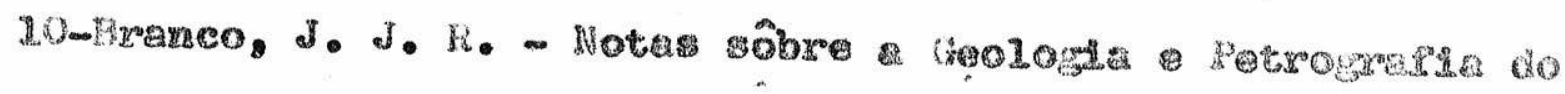




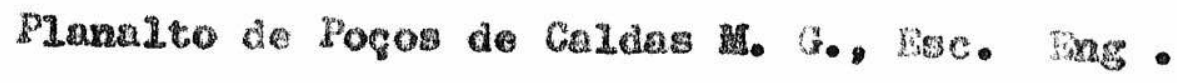

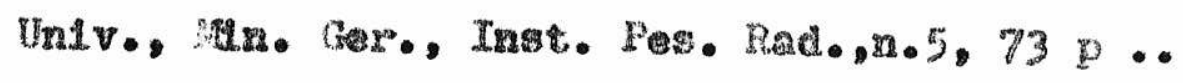
1956.

11-GaL11eux, A. - Norphoskopische Amalyse der (Aeschiebe und Ihre Bedeutung filr die Palloklinatologite, Gol. Rund. V.40, h.1, p.11-19, 1952.

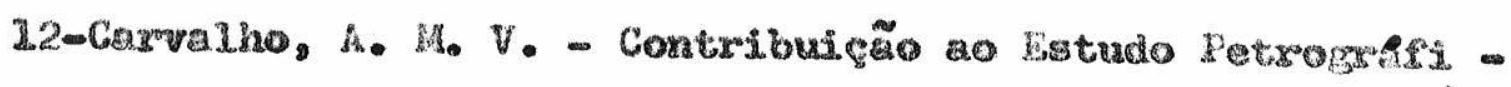
co do Aremito Botreatu no Lstado de Seio Rezrlo, B01. Soc. Bras., Geol. v.3, x..1, p.52-7. 1954.

1.30-Cloos, H. - Bau und teigkedt von turfschloten, Geol . Reund., V.32, h.2-2, p.709-799, 1941.

14- - Hoburag-SpaLtung-Vulkenismas, GeoL. Rund., v. 30, $1.405-527,1939$.

25-Daly, R. A. - Igneous Rocks and the Depths of the Rsurth, Me arew HII Book Co., Ine., 1933.

26-Derby, 0. A. - sôbr as kochas Nefelinfeas no Exrisin, ( tr) Rev., Eng., Rio de Janeiro, p.1-15, 18858.

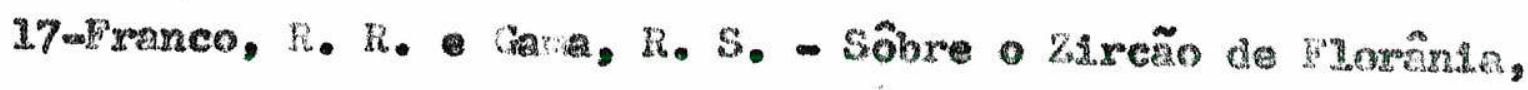
Rio Grande do Norte, Mrasi1, Bol. Soc. Brens . Geol., v.4, n.2, p.4.1-49, 1955.

18-Freitas, R. O. - As Fistruturea Flasels do Sistern de $\operatorname{san}$ ta Catarina no Planalzo de Fogos de Caldas,Bol. Assoc. (leogr. Bres., n.3, p.25-36, 1943.

19- - Lnsăo sôbre a Tectônica Hoderna do Hrasil. 120 p., Bol. Dep. Geol. Hac. Hil. G. Let. de São Paulo, n.6, 1951. 
20.

- Sedimentação, Estratigrafia e Tectônica da Se rie Bauru, (Estado de São Pauzo), $185 \mathrm{~g}$. Bol . Dep. Geol. Fac. Fil. C1. Lot. de São Paulo,n.14, 1955.

21-Handiton, W. B. - Playa sediments of Rosamond Dry Lake, California, Jour. Sed. Petr., v.21, n.3, p.147150, 1951 .

22-KrumbeIn, W. C. \& SIOss, L. L. - Stratigraphy and S̀edimen tation, w. H. Freenan \& Co. S. Fransisco, 1951.

23-Krynine, P. D. - Arkose Deposits in the Huntd Tropies. Arr. Jour. S.e., ser.5, v.29,p.353-363, 1935.

24-Lahee, F. H. - Fleld Geology, Mac. Craw Hill Book Co., Inc. 1941.

25-Leinz, V. - Estudos sôbr a ğLacLação Permo Carbonifara do Sul do Brasil, Sorv. Fom. Prod. Min. Bol.21, Rio de Janeiro. 1940.

26-Nhrtin, H. Korn, H. - The Messun Igneous Complex in Sou th West Africa, Trans. Proc. Geol. Soc. S. Afr. ข.LVII, p.834-122, 1954 .

27-lleliner, H. B. - Sedimentary Petrography, Thomas Hixurby is Co., Jondon, 1952.

28-Pettijohn, F.J. - Sedimentary Rocks, hlarper ic Bros., Now York, 1952.

29-ieichenbach, H. - Eldments of Symbolic Logic, He Malian Co., New York, 1952. 
30-Russe11, R. D. e Taylor, R. E. - Roundness and shape of Mastssipi River Sands, Jour. Geol., vol.45, p. $239-248,2937$.

31-Shand, S. J. - The Geology of P1lannberg fir the Western Transvaal, Trans. Geol. Soc. S. Afx., v.XXXX., p. 97-156, 1929.

32-Sitter, L. U. de - Structura Geology, p.373-374, Nec Graw Hill Book Co. Inc., Michigan, 1948.

33-Iurnex, F. J. Verhoogen, J. - Igneous and Hetamorphic Petrology, Mac Grew H111 Book Co., Inc., 1951. 34-Twenhoffel, W. H. - Principles of Sedimentation, Mac Graw H111 Book Co. Inc., Now York, 1950.

35-Umbgrove, \. H. F. - The Pulse of the Earth, Martenus NIJhoff, 1947.

36-Wadde1, 1. - Volume, Shape and Roundness of Pexticles, Jour. Geol., v.40, p.443-451, 1932. 


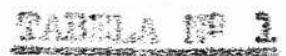

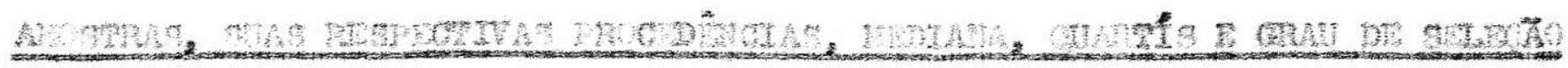

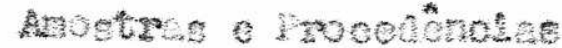

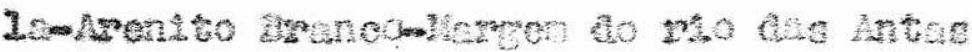

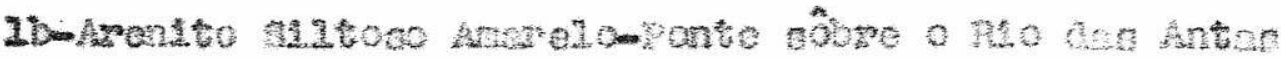

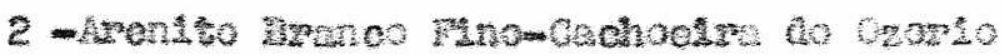

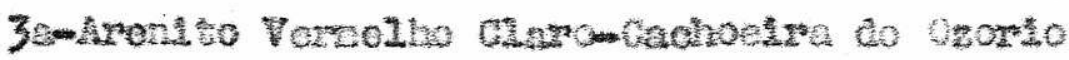

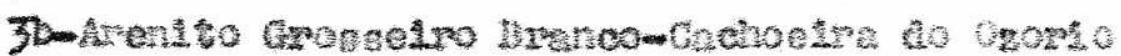

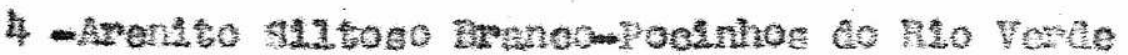

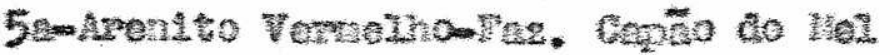

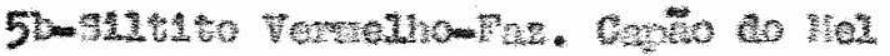

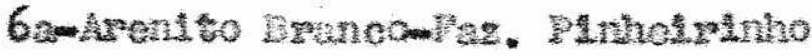

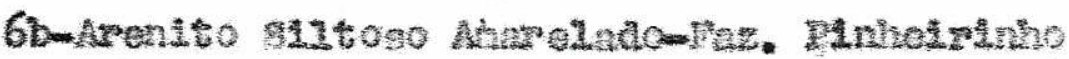

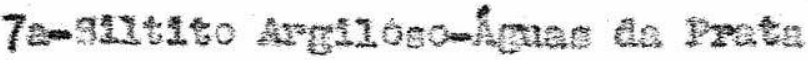

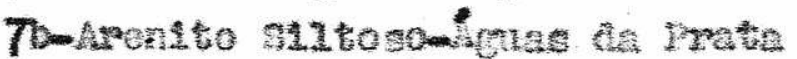

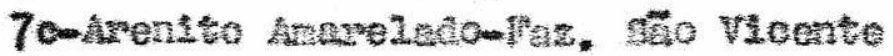

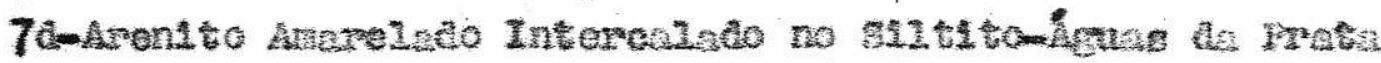

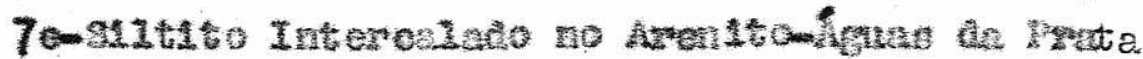

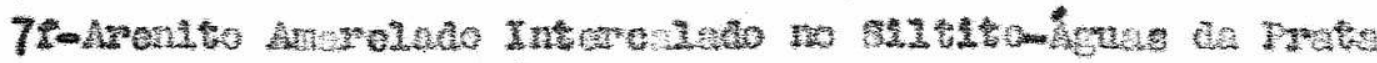

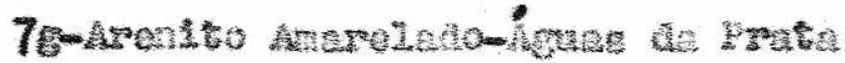

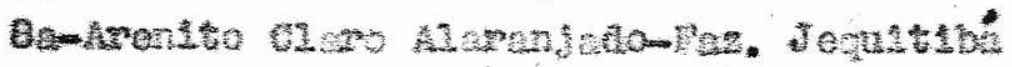

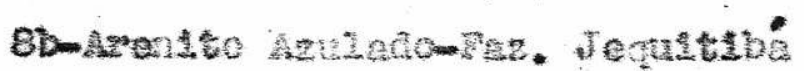

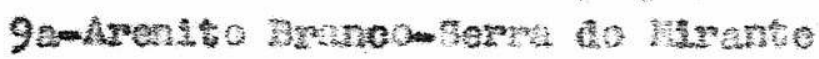

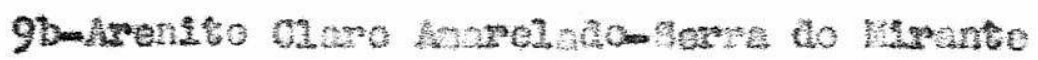

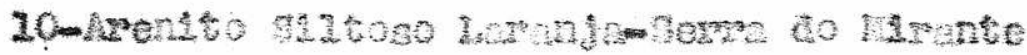

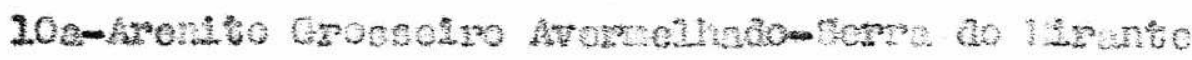

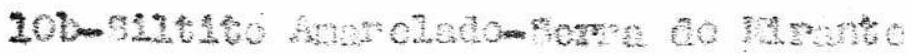

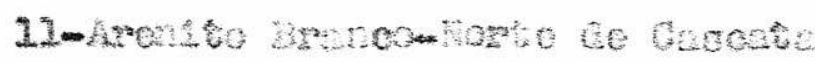

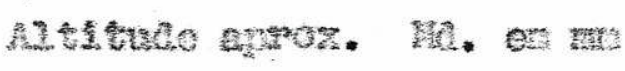

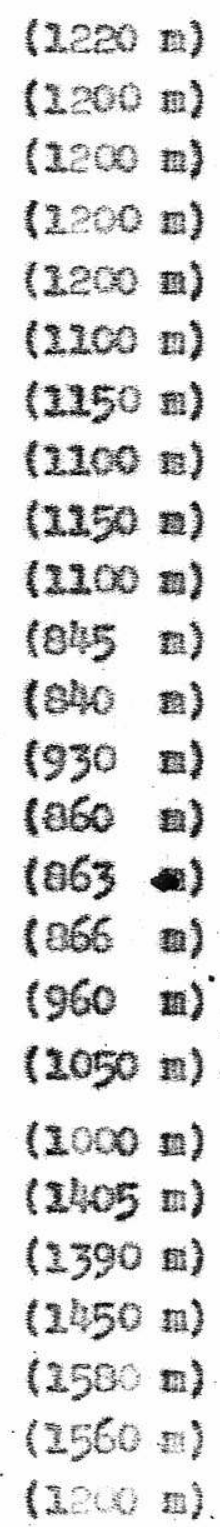

\begin{tabular}{|c|c|}
\hline 0.27 & 0.20 \\
\hline 0,37 & 0,30 \\
\hline 0.25 & 0,41 \\
\hline 0,27 & 0,55 \\
\hline 0,50 & 1,06 \\
\hline 0,27 & 0,40 \\
\hline 0.36 & 0.30 \\
\hline 0,03 & 0,0 \\
\hline 0,22 & 0,29 \\
\hline 0.27 & 0,10 \\
\hline $0,00 e^{15}$ & 0,0075 \\
\hline 0,03 & 0,20 \\
\hline 0,38 & 6,48 \\
\hline 0,21 & 0.29 \\
\hline $0,0_{4}$ & 0,07 \\
\hline 0,16 & 0,20 \\
\hline 0,37 & 0.54 \\
\hline 0,26 & 0,21 \\
\hline 0,20 & 0,36 \\
\hline 0.15 & 0,25 \\
\hline 0.32 & 0.39 \\
\hline 0,54 & 0,76 \\
\hline 0,26 & 0,36 \\
\hline 0,12 & 0,27 \\
\hline $0,3 \%$ & 0,24 \\
\hline
\end{tabular}

2

0,12

$0,2+$

0,37

0,16

0,27

0,23 .

0,33

0,02

0,10

0,29

0, ne2

0,000

0,24

0.31

0,03

0,23

0,20

0,06

0,03

0,10

0,21

0,25

0,00

0,0

$0, \infty$
90.

2,4

1,3

1.6

1,9

2.5

1,8

1,1

1,

1,3

1,5

1,0

3,6

1,4

1,6

1,5

1,2

1,15

1,9

2,3

1.6

1,4

1,6

2,2

2,0

1,6 


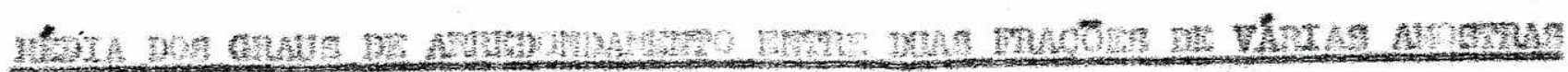
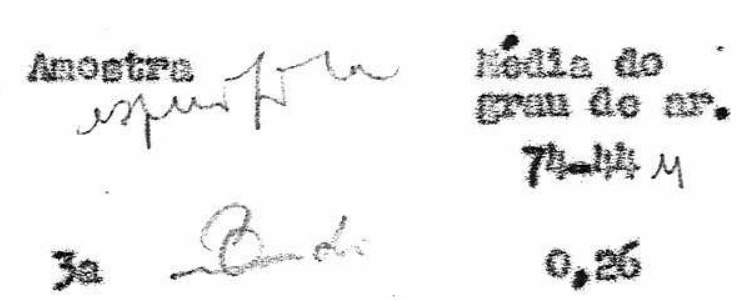

0,20

$20 \mathrm{at}$

200

IA

chats:

Ar. Botwentat

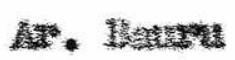

Huwa-ghaefa:

\begin{tabular}{|c|c|}
\hline $\begin{array}{l}\text { Wedata do } \\
\text { grat de ar. } \\
500-297 \text {. }\end{array}$ & Anoetrea \\
\hline 0,26 & 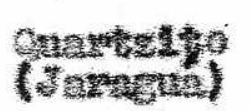 \\
\hline 0,30 & (nuartiato \\
\hline
\end{tabular}

0,43

0,27

0,15

$0, y^{4}$

0,30

0,32

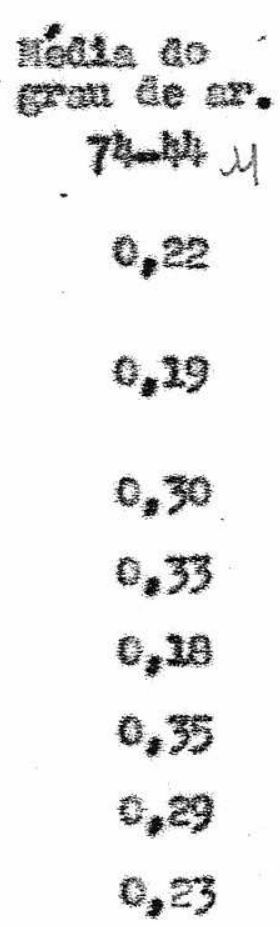

nóas as a grat de we $500-2974$

0,13

0,25

0,29

0,38

0,32

0,37

0,25

0,23 


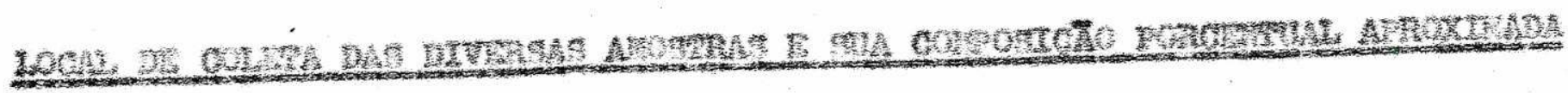

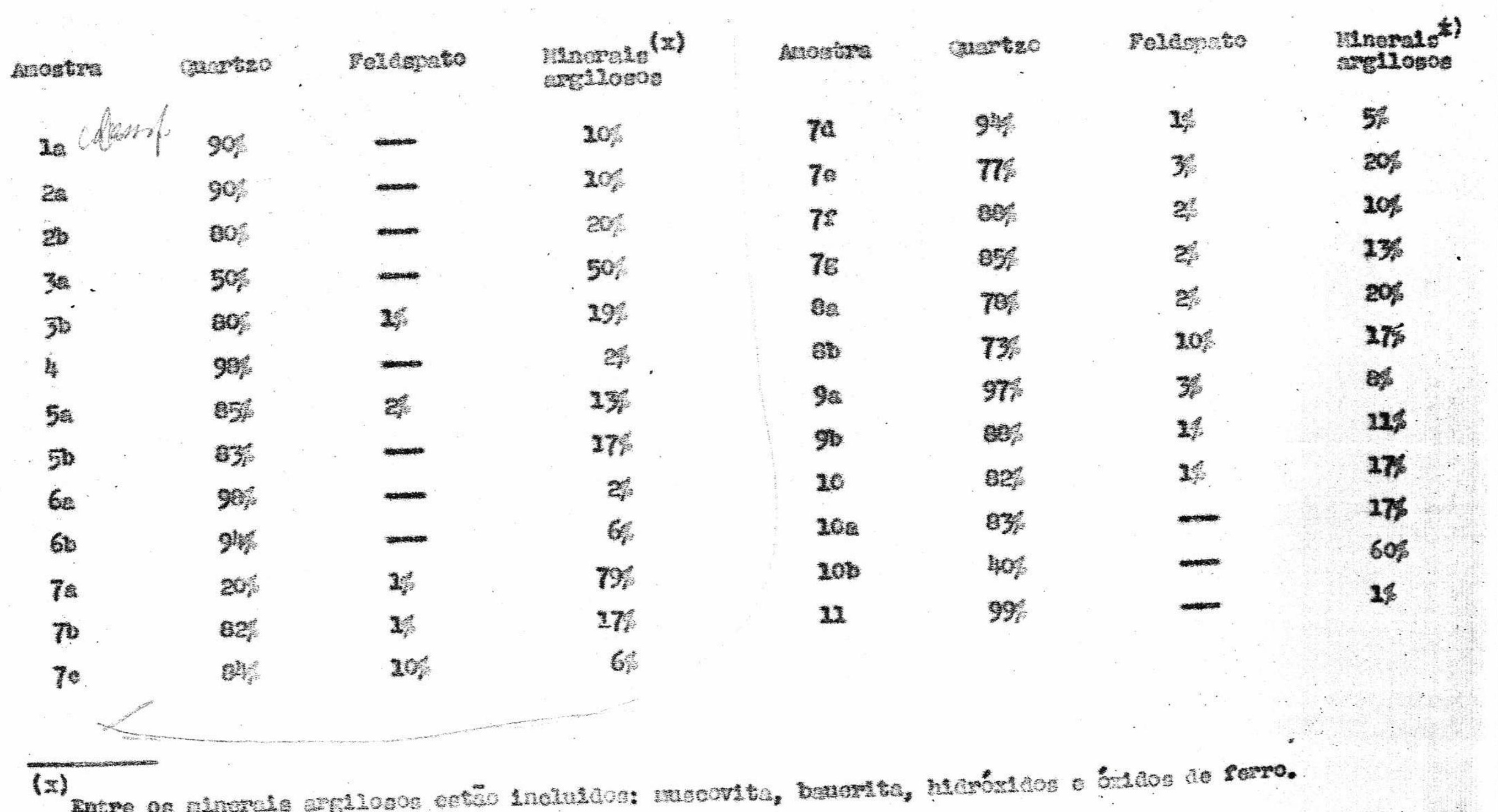




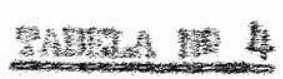

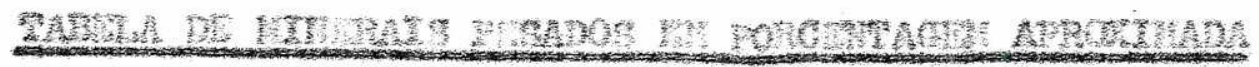

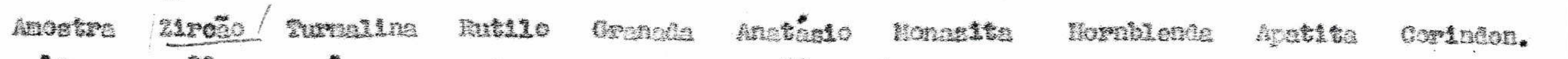

\begin{tabular}{|c|c|c|c|c|}
\hline 12 & 60 & 2 & - & \\
\hline 1b & 70 & 2 & $=$ & - \\
\hline 2 & 60 & - & $=$ & 20 \\
\hline $3 a$ & 200 & - & - & - \\
\hline 30 & 50 & - & - & 2 \\
\hline 4 & 75 & 2 & 7 & - \\
\hline $5 a$ & 58 & 5 & - & - \\
\hline 50 & - & - & - & - \\
\hline $6 s$ & - & - & - & - \\
\hline 60 & - & - & - & - \\
\hline $7 a$ & 73 & 9 & 27 & $=$ \\
\hline 70 & 50 & 35 & 15 & - \\
\hline 70 & 76 & 9 & 19 & - \\
\hline $7 a$ & 42 & 42 & 9 & 3 \\
\hline 70 & 64 & 7 & 33 & - \\
\hline 75 & - & - & $=$ & - \\
\hline $7 s$ & 50 & 40 & 10 & - \\
\hline Ba & 55 & 6 & 15 & - \\
\hline $\mathrm{sb}$ & 50 & - & - & 7 \\
\hline 92 & 50 & - & - & - \\
\hline 90 & 65 & - & 2 & $=$ \\
\hline 20 & 60 & - & 23 & - \\
\hline $20 \mathrm{a}$ & 40 & - & - & - \\
\hline $20 b$ & 33 & - & $=$ & 2 \\
\hline 21 & 76 & - & - & \\
\hline
\end{tabular}

20
$=$
-
40
$=$
$=$
-
-
-
$=$
-
-
20
32
50
40
20
50
63
20

-
-
-
-
-
-
-
-
1
2
-
-
-
-
-
-
-
-
-

-
-
-
-
-
-
-
-
-
-
-
-
-
-
-
-
-
-

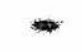

$-$

$-$

$-$

$-$

$-$

-

$-$

$-$

$-$

2

$-$

2

-

2

$-$

$-$

$-$

$-$

$-$

$-$ 


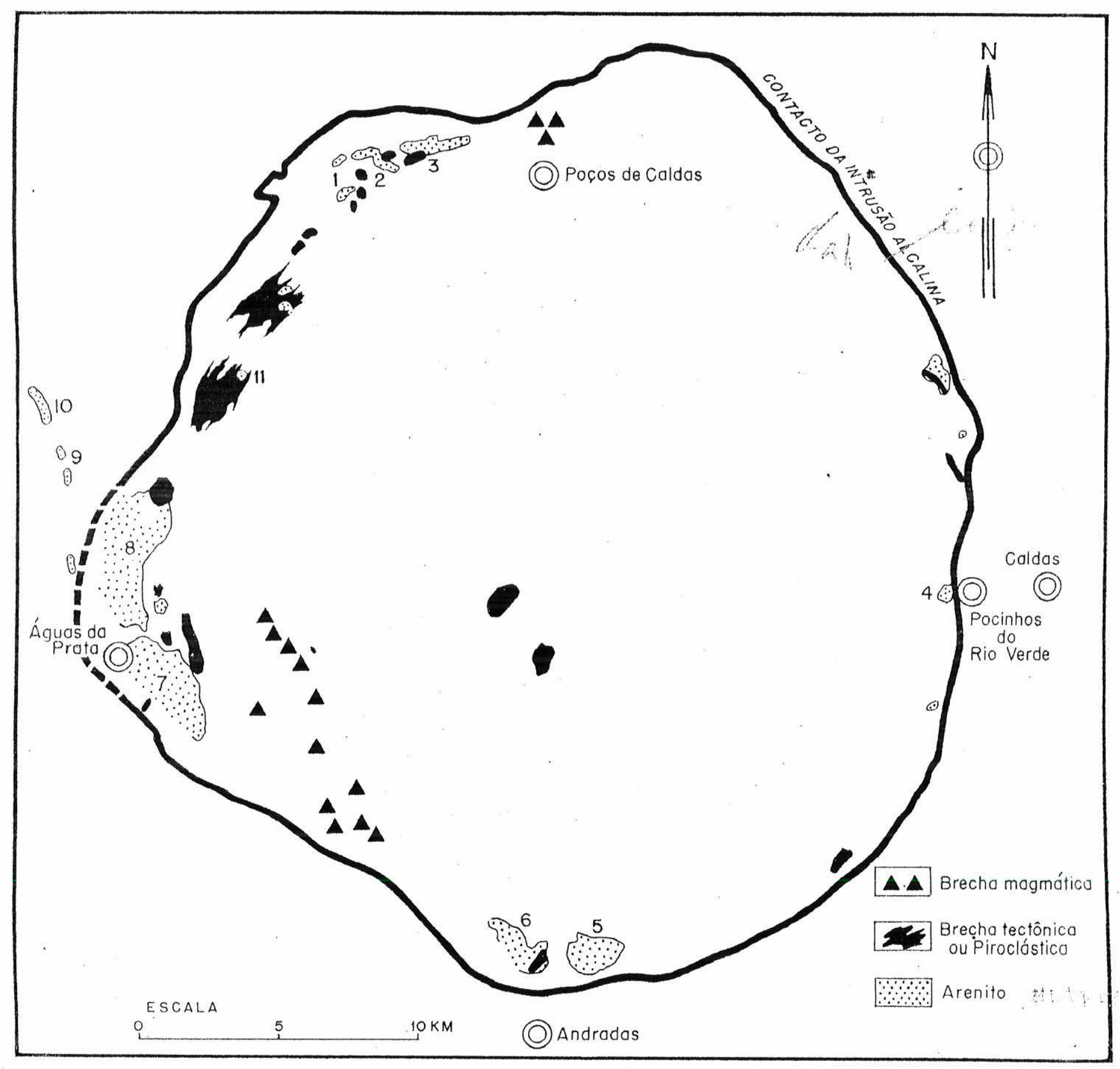

Fig. 1

Mapa do planalto de Poços de Caldas com delimitação esquemá tica dos afloramentos de rochas clasticas. 


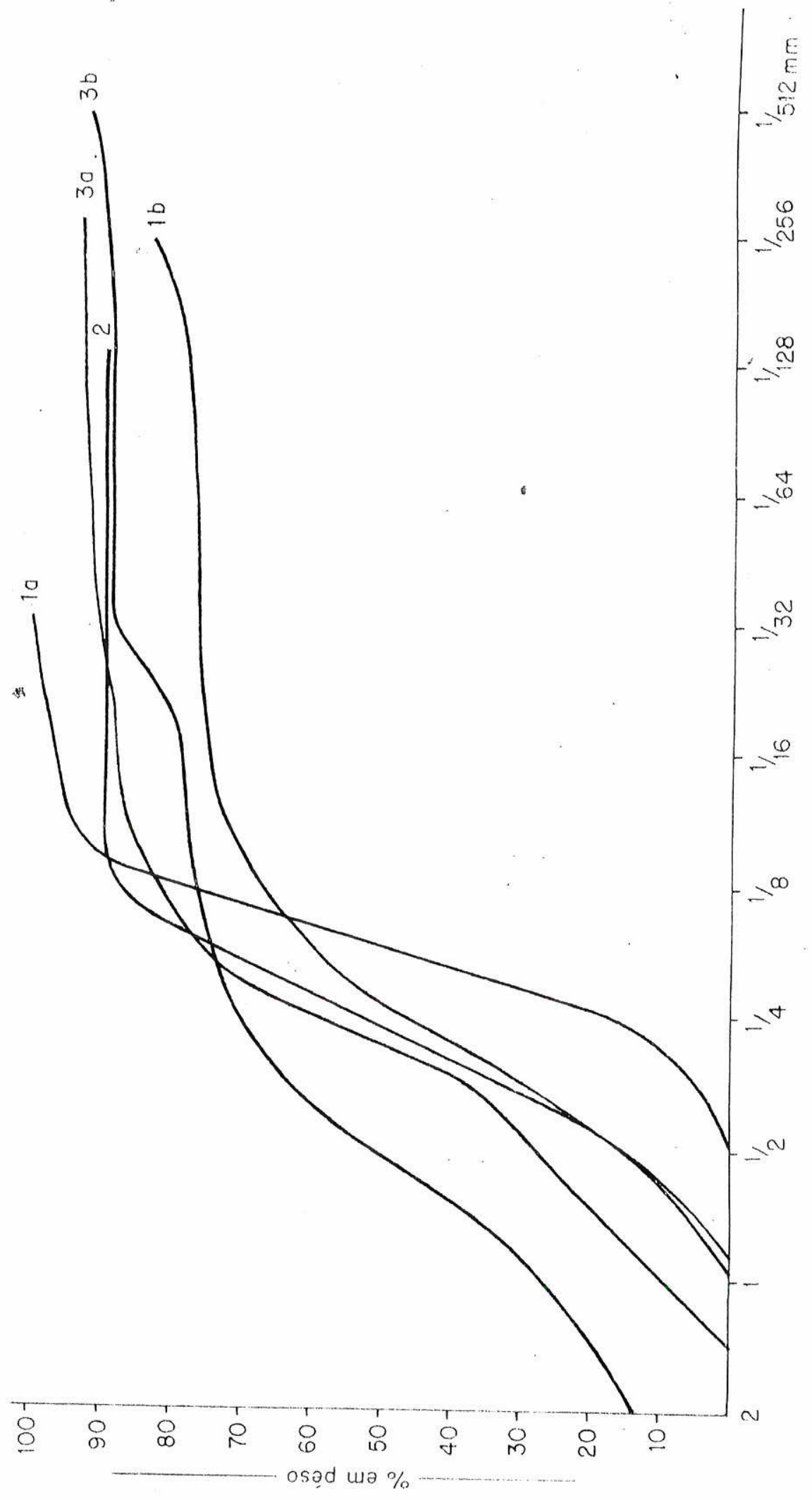

Fi., 2

Sedimentos do quadrante norte do planalto alcalino 


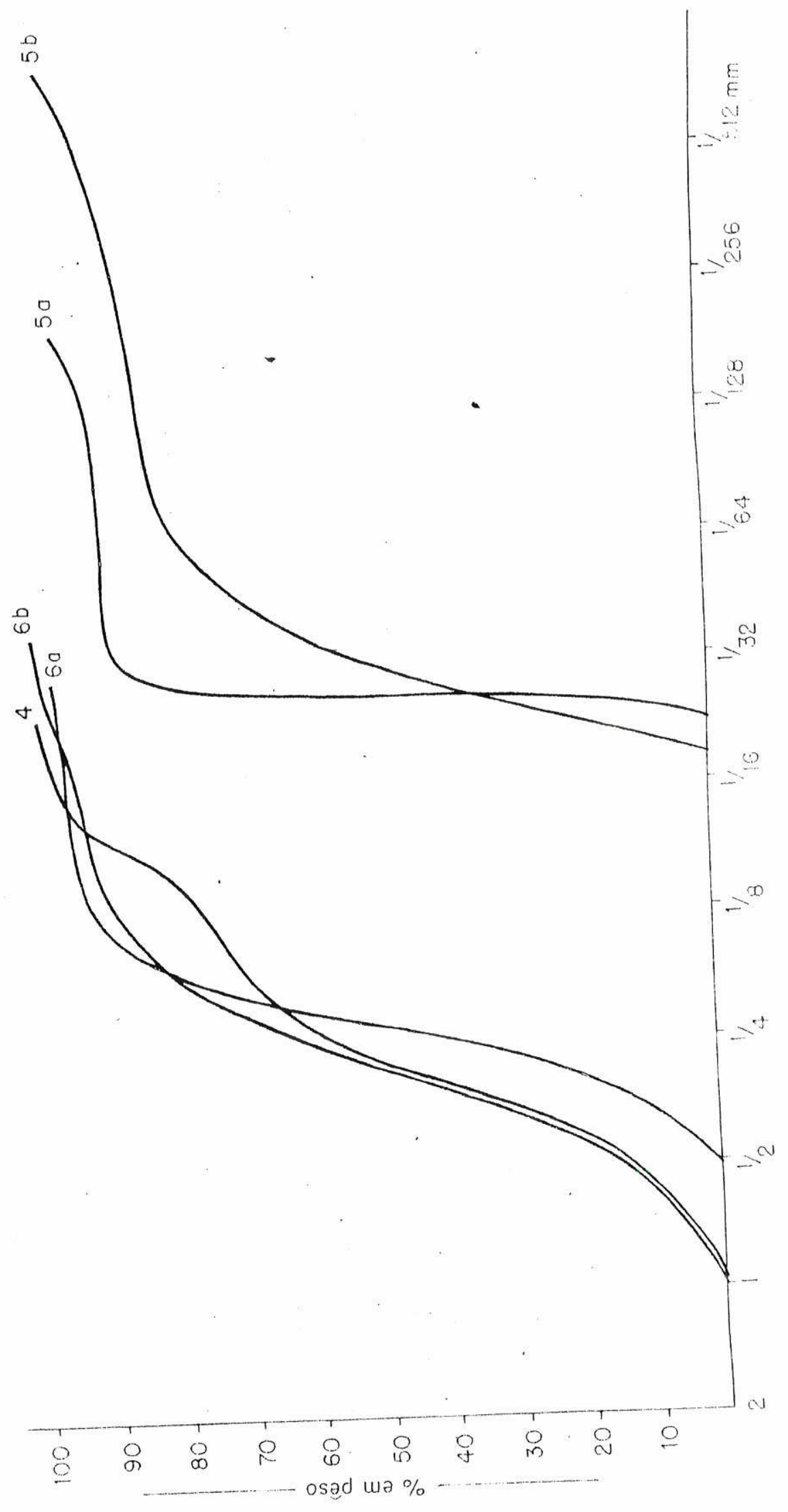

Fjg. 3

Sedimentos do quadrante este e sul do planalto alcalino 


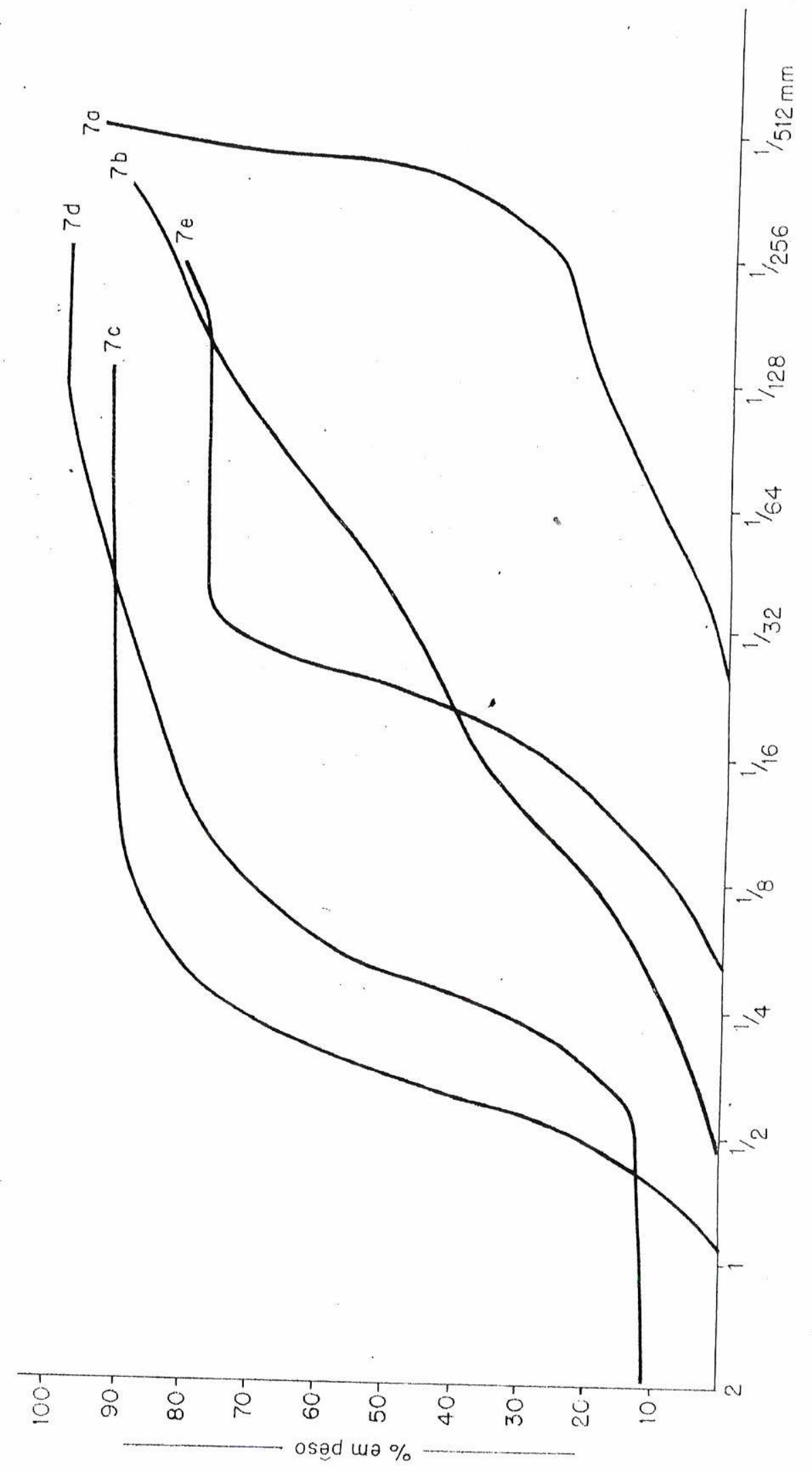

Fig. 4

Sedimentos arenosos e siltosos da borda oeste do planalto al. lino de foços de Caldas 


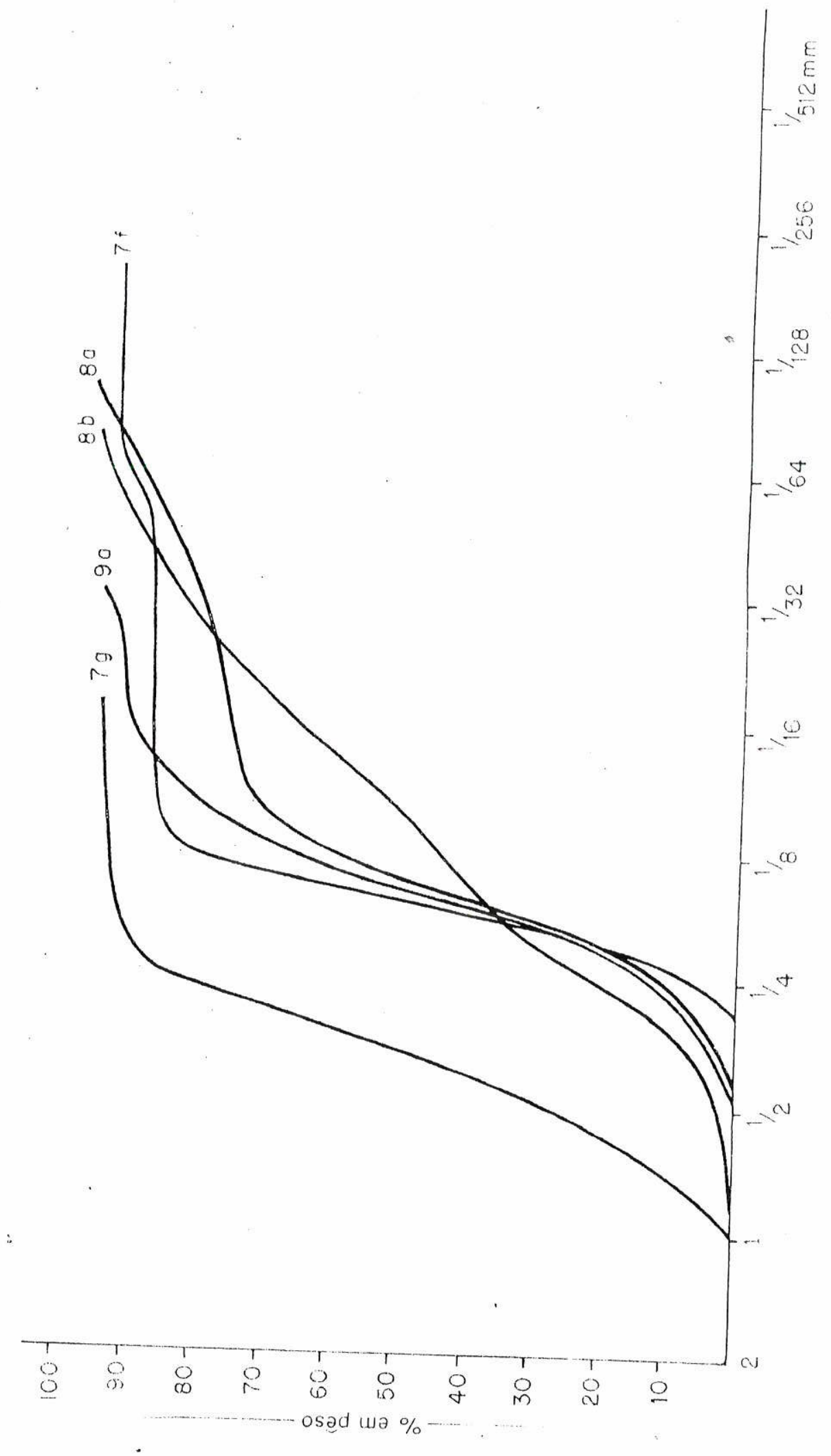

Fig. 5

Sedimentos arenosos do quadrante oeste do planalto alcalino 


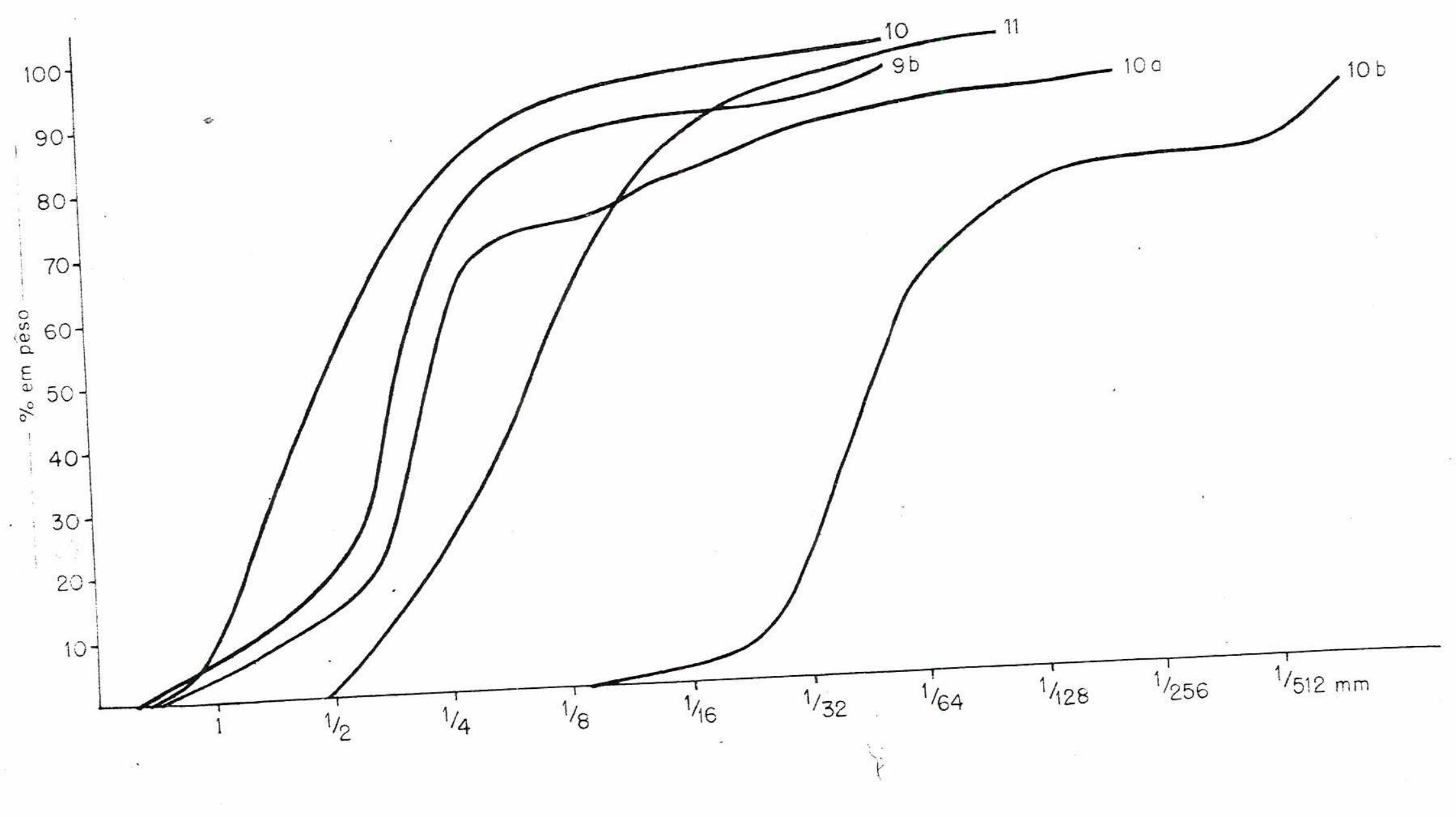

Fig. 6

tos do quadrante noroeste do planalto de Foços de Caldas Arenitos do quadrante noroeste do planalto de toços de baduo 


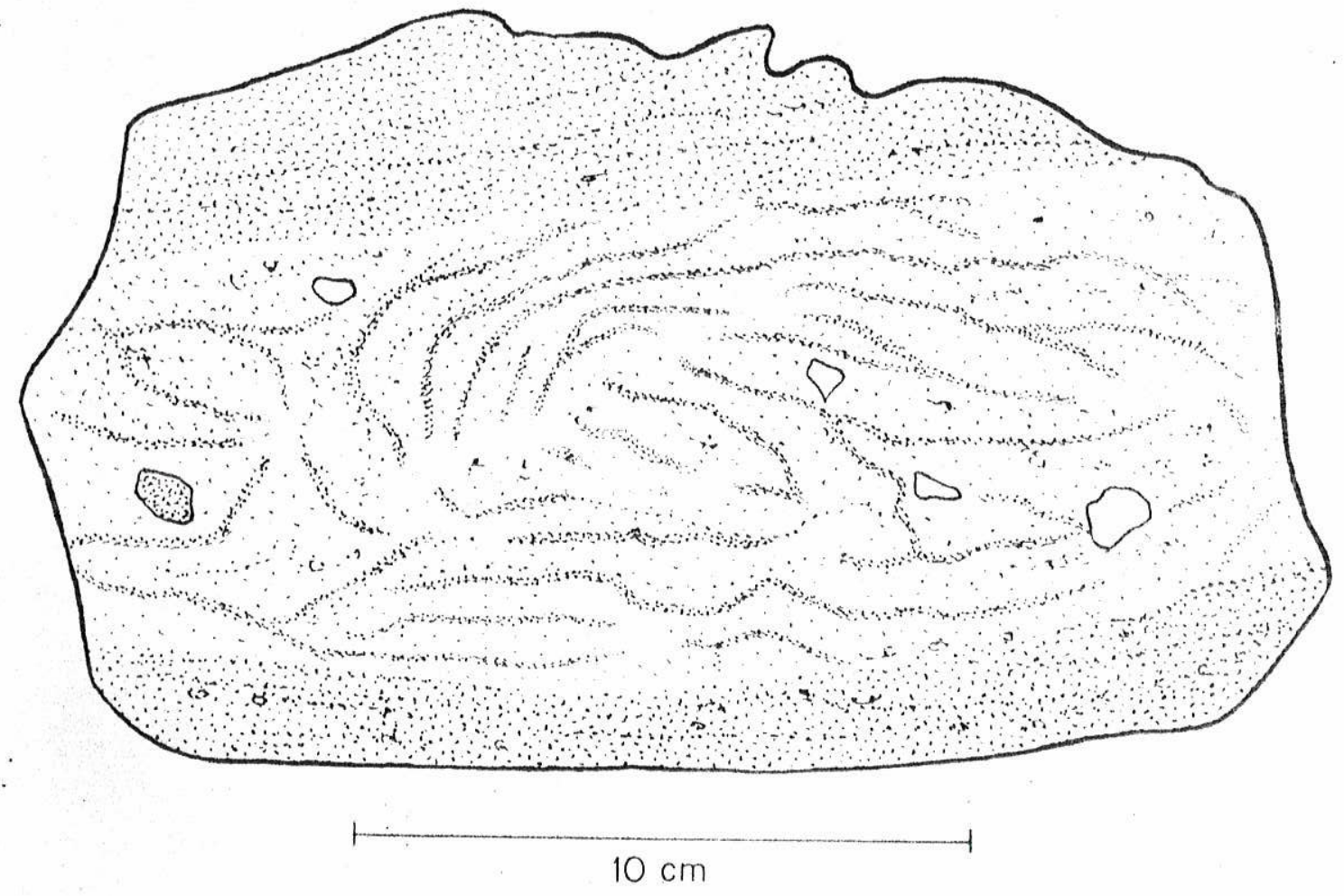

Fig. 7

Fragmento de rocha clástica arenosa arcosiana

(Serra do Mirante) 


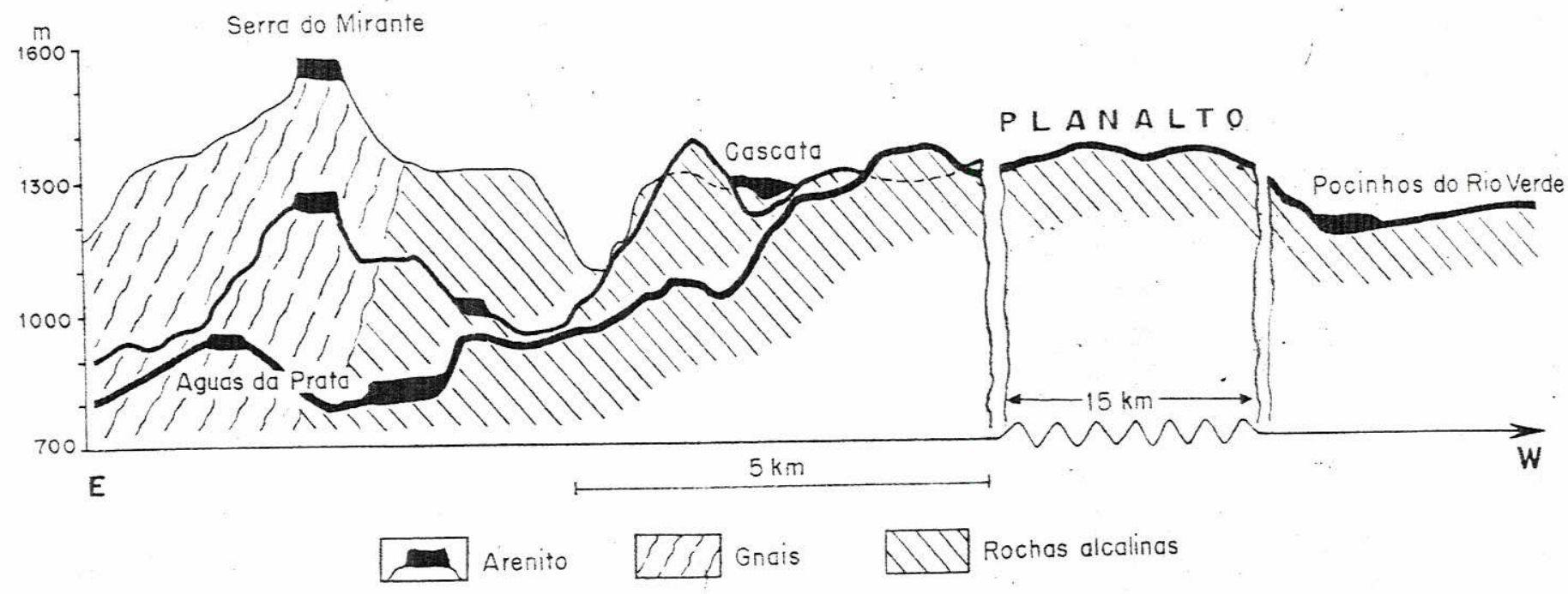

Fig. 8

Esquera de três perfls E-W de Rguas da Frata para o norte dis tanciados de 3,5 quilsmetros aproximadamente 


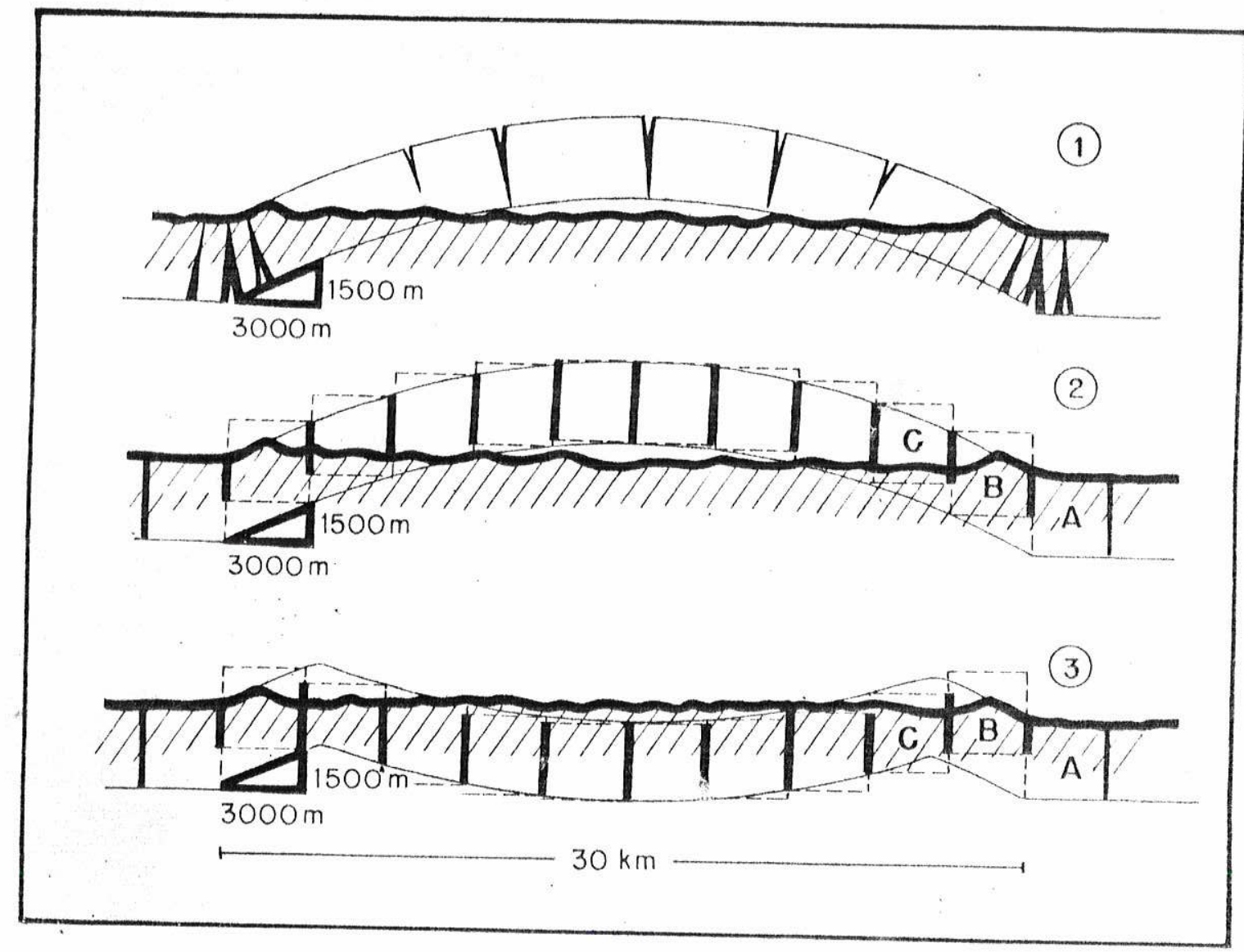

Fig. 9

Esquemas estruturais especulativo 


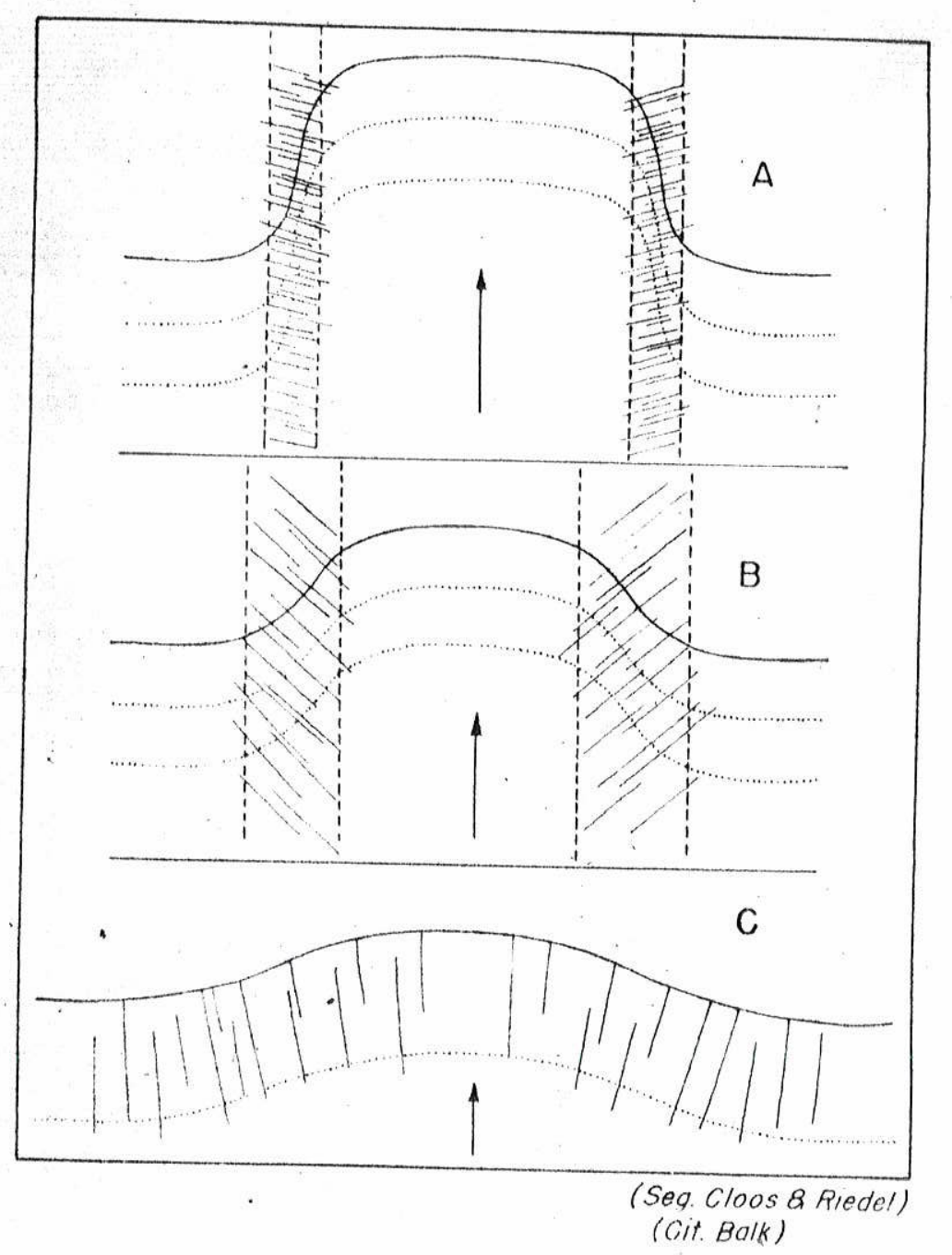

Fig. 10

Esquema dos resultados experimentais fornecidos por massa que se move ao longo de obstrução estacionária 


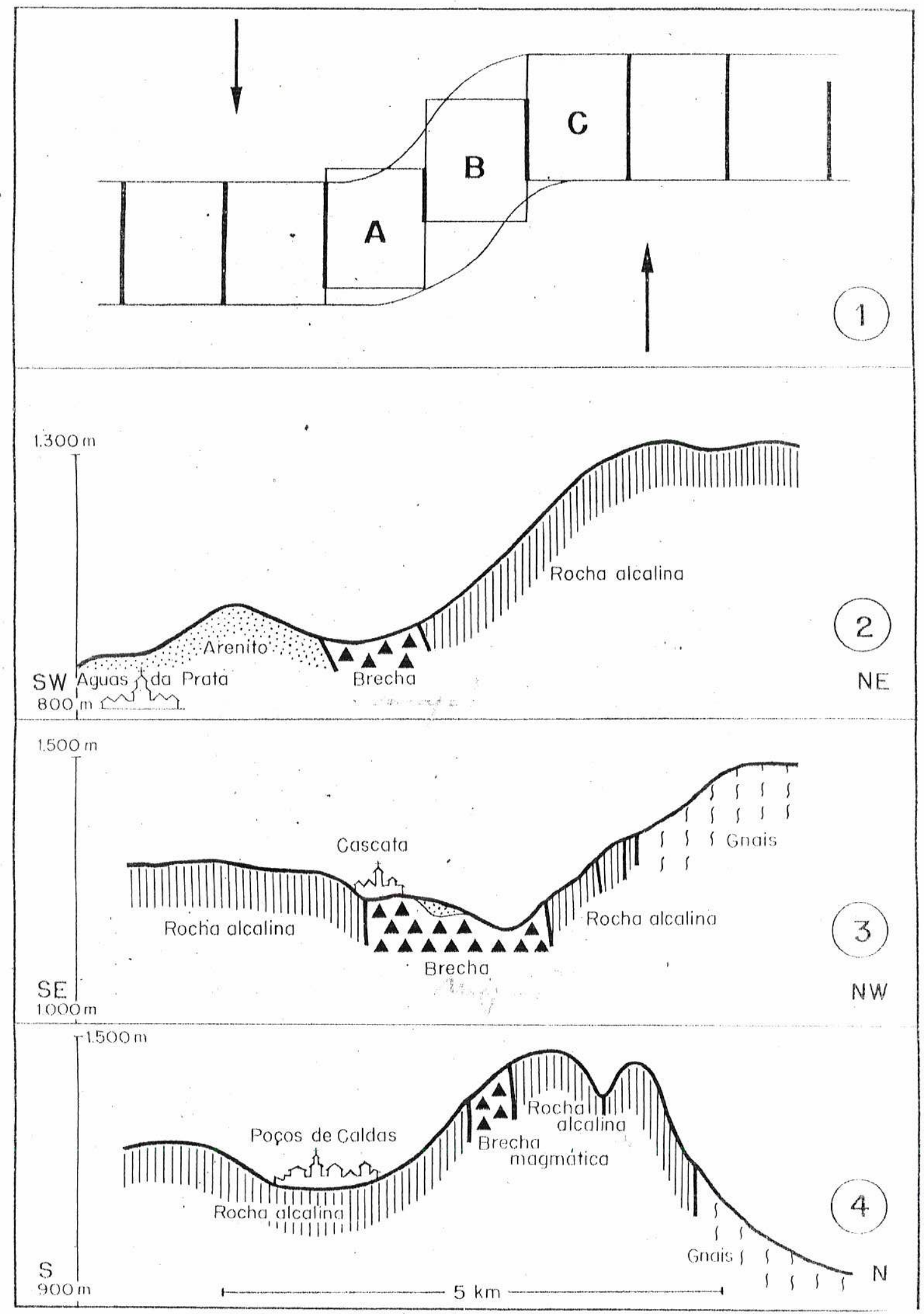

Fig. 11

Um perfil teórico dos blocos movimentados e três reais do - contacto rocha alcalina e encaixante 


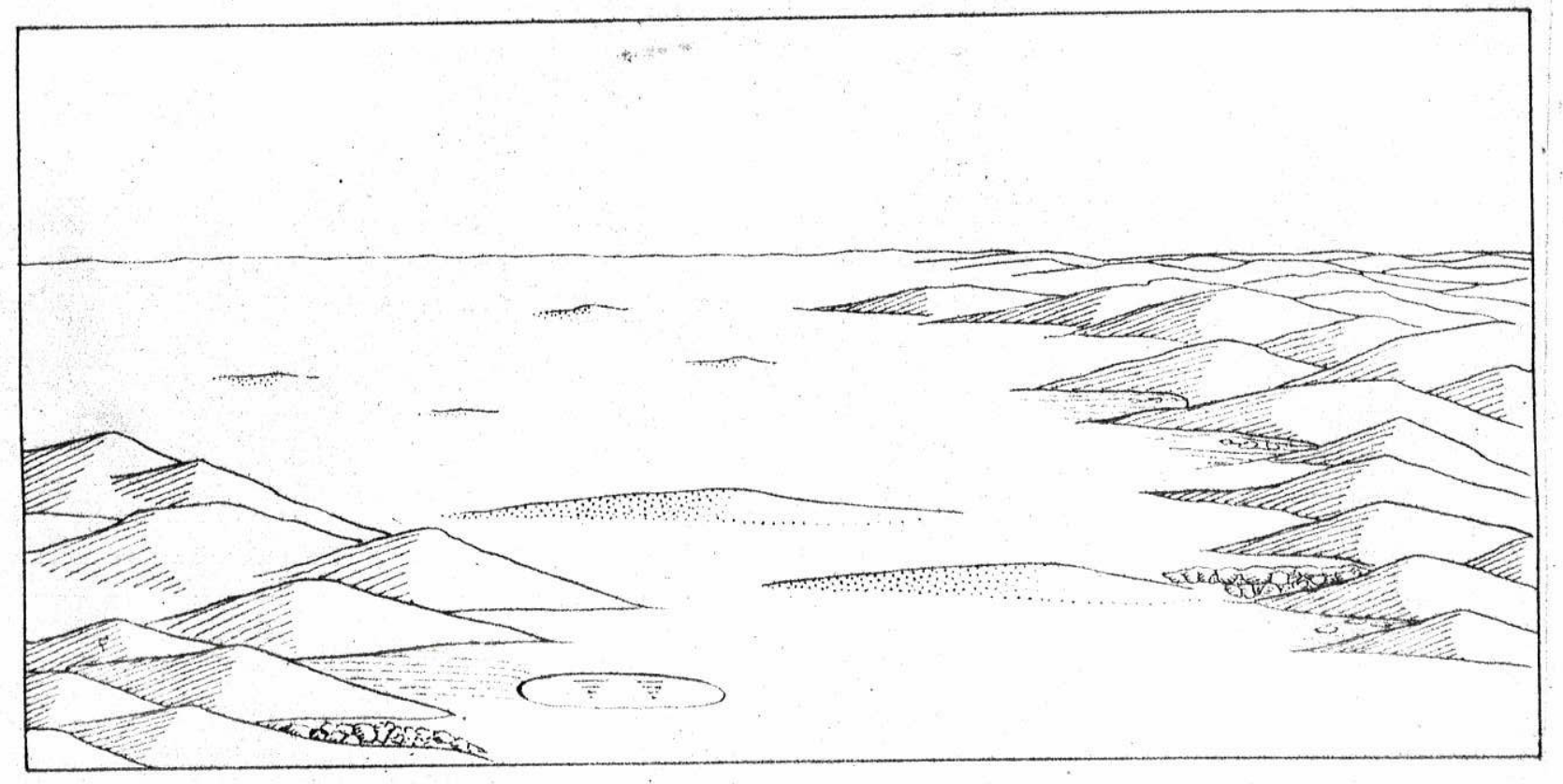

Fig. 12 a

Fase pre intrusão

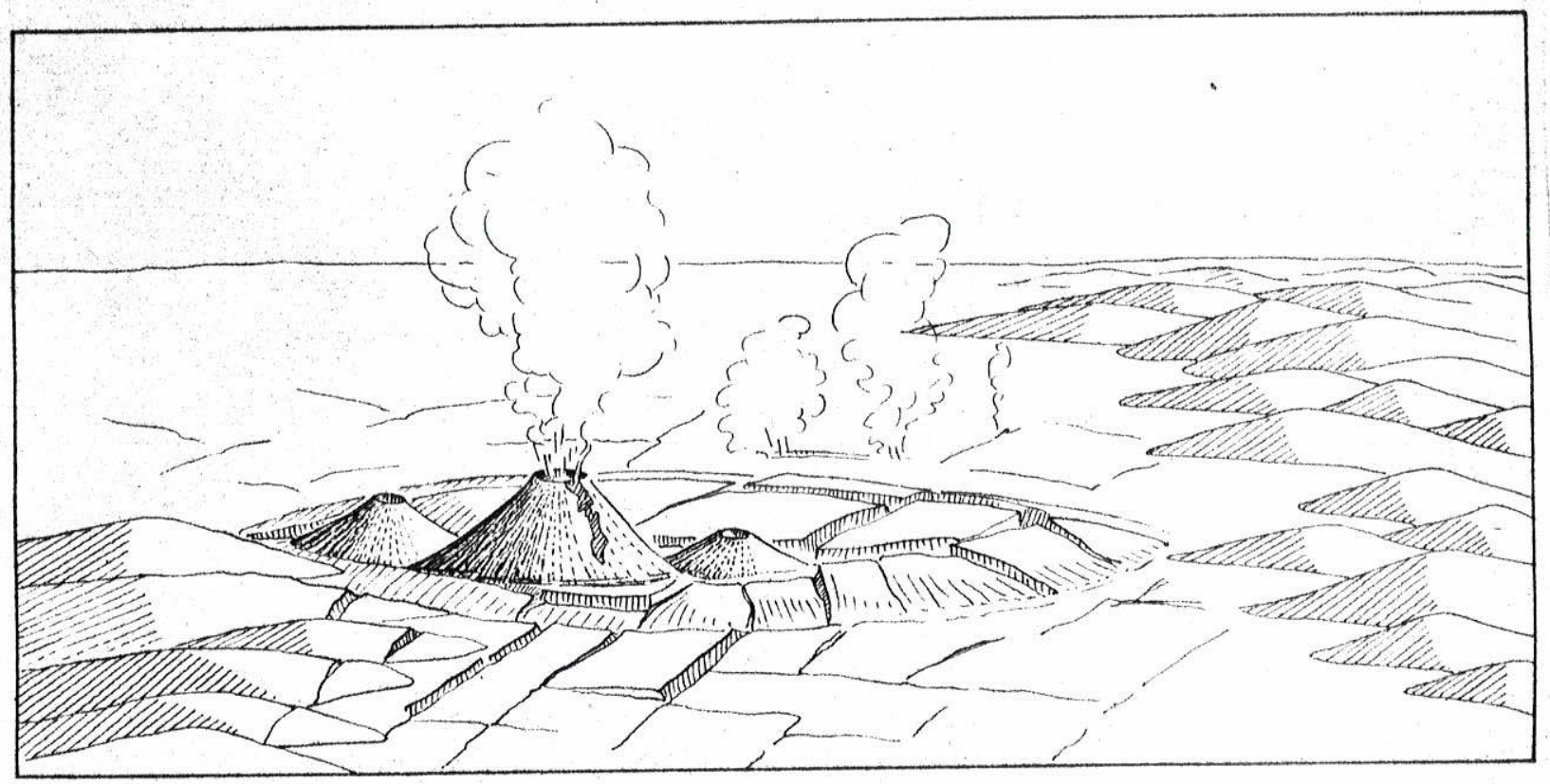

Fig. 12 b

Fase provável de intrusão e vulcanismo 